\title{
Multiple NPY Receptors Coexist in Pre- and Postsynaptic Sites: Inhibition of GABA Release in Isolated Self-Innervating SCN Neurons
}

\author{
Gong Chen and Anthony N. van den Pol \\ Section of Neurosurgery, Yale University School of Medicine, New Haven, Connecticut 06520
}

\begin{abstract}
Although NPY has been shown to influence the action of many transmitters in the brain, modulation of GABA, the primary inhibitory transmitter, has not been detected with electrophysiology. Using whole-cell patch-clamp recording, we found that NPY has a large modulatory effect on GABAergic neurons of the suprachiasmatic nucleus (SCN) that act as the circadian clock in the mammalian brain. NPY, acting at both Y1- and Y2-like receptors, reduced the frequency of spontaneous miniature inhibitory postsynaptic currents while having little effect on the postsynaptic GABA receptors, suggesting a presynaptic mechanism of NPY action. In single self-innervating neurons, application of either $\mathrm{Y} 1$ or $\mathrm{Y} 2$ agonists to the same neuron significantly inhibited the evoked autaptic GABA release. The use of
\end{abstract}

single-neuron microcultures has allowed the demonstration that a single peptide, NPY, has two different receptors coded for by different genes in the same axon terminal. The $Y 1$ and $Y 2$ agonists also inhibited whole-cell calcium currents when applied to the same neuron, indicating a coexistence of $Y 1-$ and Y2-like receptors in the postsynaptic cell body. The selfinnervating cell model we use here may be applicable generally for discriminating presynaptic versus postsynaptic actions of other neurotransmitters and neuromodulators and locating their subtype receptors.

Key words: NPY; GABA; suprachiasmatic nucleus; NPY receptor; Y1-Y5 receptors; presynaptic; postsynaptic; autapse; microculture
The suprachiasmatic nucleus (SCN) of the hypothalamus controls circadian rhythms in mammals (Moore and Eichler, 1972; Stephan and Zucker, 1972; Inouye and Kawamura, 1979; Ralph et al., 1990; van den Pol and Dudek, 1993). NPY is found in axons in the SCN that originate in the intergeniculate leaflet (Harrington et al., 1985; Card and Moore, 1989; Botchkina and Morin, 1995). The SCN contains one of the highest concentrations of NPY in the mammalian CNS (Allen et al., 1983; Chronwall et al., 1985; Pelletier, 1990). Most SCN neurons are GABAergic (van den Pol and Tsujimoto, 1985; Okamura et al., 1989; Moore and Speh, 1993), and GABA is found in 50\% of all presynaptic axons in the SCN (Decavel and van den Pol, 1990). Many of these arise from intrinsic axons of the SCN (van den Pol, 1980). GABA may be colocalized with NPY in some SCN axon terminals (Francois-Bellan et al., 1990). NPY administration into the SCN phase shifts the circadian rhythms (Albers and Ferris, 1984; Shibata and Moore, 1993), and the GABA receptor antagonist bicuculline can block this phase shift (Huhman et al., 1995), suggesting a functional interaction between GABA and NPY in SCN. Although NPY can play an important role in SCN phase shifts (Albers and Ferris, 1984; Moore and Card, 1990; Shibata and Moore, 1993), little is known about the cellular mechanisms of NPY action in the SCN.

NPY may activate different subtypes of receptors. In the past NPY receptors generally have been divided into two cloned types, Y1 and Y2 (Wahlestedt et al., 1990; Herzog et al., 1993; Colmers

Received June 20, 1996; revised Aug. 29, 1996; accepted Sept. 5, 1996.

This work is supported by National Institutes of Health Grants NS 34887 and NS 10174, the National Science Foundation, and the Air Force Office of Scientific Research. We thank Dr. Y. Yang for technical help.

Correspondence should be addressed to Dr. Anthony van den Pol, Section of Neurosurgery, Yale University School of Medicine, 333 Cedar Street, New Haven, CT 06520.

Copyright (C) 1996 Society for Neuroscience $0270-6474 / 96 / 167711-14 \$ 05.00 / 0$ and Bleakman, 1994; Gerald et al., 1995; Nakamura et al., 1995; Rose et al., 1995). With the recent cloning of new NPY receptors, including Y4 (Bard et al., 1995) and two different Y5 receptors, one cloned from mouse (Y5m, Weinberg et al., 1996) and one cloned from rat (Y5r, Gerald et al., 1996), the pharmacology of NPY actions has become more complicated. However, in some limited respects, Y4 and Y5 receptors show different sensitivity to Y1 and Y2 agonists and can be considered to demonstrate preferential Y1- or Y2-like properties.

NPY is one of the most abundant peptides in the nervous system (Tatemoto et al., 1982; Adrian et al., 1983). Cytochemically, NPY colocalizes with neurotransmitters such as noradrenaline (Simonneaux et al., 1994), GABA (Hendry et al., 1984) and other peptides (Chronwall et al., 1984) in presynaptic nerve terminals. NPY receptors modulate neurotransmitter release (Wahlestedt et al., 1986; Colmers et al., 1987, 1991; Wiley et al., 1990; Simonneaux et al., 1994), hormone and peptide secretion (McDonald et al., 1985; Walker et al., 1988; Kalra et al., 1992; Larsen et al., 1994; Scheenen et al., 1995), whole-cell calcium currents (Bleakman et al., 1991; Wiley et al., 1993; McQuiston et al., 1996), and gene expression (Li et al., 1994; Garcia de Yebenes et al., 1995) in both peripheral and CNS.

In a previous study based on digital imaging, we found that NPY reduced GABA-mediated calcium rises in synaptically coupled developing neurons (Obrietan and van den Pol, 1996). In the present study, we investigated the mechanism and site of action of NPY modulation in SCN neurons at the single-cell level by using whole-cell patch-clamp recording to study single self-innervating (autaptic) neurons in a microculture model. Autaptic connections have been reported in the SCN on the basis of ultrastructural evidence (Guldner and Wolff, 1978) and in other brain regions such as the cortex (Lubke et al., 1996). Autaptic neuron microcultures have been found to be a useful tool in elucidating syn- 
aptic functions, especially in establishing the amino acid transmitter identity of living neurons (Furshpan et al., 1986; Bekkers and Stevens, 1991; Johnson, 1994). Furthermore, the same mechanisms and neurotransmitters that exist in cultured neurons also have been detected in homologous regions in vivo or in brain slices. Single SCN neurons in multicelled cultures express circadian rhythms of electrical activity similar to the electrical rhythms found in vivo (Bos and Mirmiran, 1990; Welsh et al., 1995). Even epileptiform electrical activity and long-term potentiation have been found in single isolated neurons from regions of the brain where the same phenomena are found in situ (Segal, 1991, 1994; Tong et al., 1996).

In the present paper we use single self-innervating neurons primarily because they provide a simple model system to study the mechanisms of action of modulators on neurotransmission in the absence of the large number of heterogeneous synaptic interactions that occur in brain slices or in multicelled cultures. This is important in light of the different NPY responses that have been reported in the SCN with extracellular recording in slices that include excitation (Mason et al., 1987), inhibition or excitation (Albers et al., 1990), or excitation followed by inhibition (Liou and Albers, 1991). We demonstrate here with single-neuron microcultures that NPY Y1- and Y2-like receptors coexist in the same SCN neuron and that both receptors mediate the inhibition of presynaptic GABA release and postsynaptic whole-cell calcium currents. The single self-innervating neuron microculture seems to be a useful model to differentiate presynaptic versus postsynaptic effects of transmitters and their modulators and to locate subtype receptors in a single neuron.

\section{MATERIALS AND METHODS}

\section{Cell culture}

Two types of SCN cultures were used in the present study. One was a multicellular culture with a high density of neurons in the culture dish that formed a substantial number of synaptic connections. The other was a microculture of single isolated neurons in microislands.

Multicellular culture. The multicellular culture of SCN neurons is similar to previously described cultures of hypothalamic neurons (Chen et al., 1995). Briefly, the brain was taken from postnatal 1-d-old Sprague Dawley rats anesthetized with Nembutal and cut coronally in $400 \mu \mathrm{m}$ brain slices, and the suprachiasmatic nuclei were punched out with beveled hollow needles $(22 \mathrm{G})$ or dissected out by fine forceps from the brain slice containing the chiasma. The SCN tissues were then incubated for 30-40 min in an enzyme solution containing $10 \mathrm{U} / \mathrm{ml}$ papain, $0.5 \mathrm{~mm}$ EDTA, 1.5 $\mathrm{mM} \mathrm{CaCl}$, and $0.2 \mathrm{mg} / \mathrm{ml} \mathrm{L-cysteine.} \mathrm{After} \mathrm{enzyme} \mathrm{treatment,} \mathrm{the} \mathrm{tissues}$ were washed twice with culture medium and mechanically triturated in culture medium to dissociate cells. After centrifuging $(1600 \mathrm{rpm})$ and discarding the supernatant to remove the debris of dead cells or connective tissues, we resuspended the cells and plated them on the center of coverslips coated with poly-D-lysine $(1 \mathrm{mg} / \mathrm{ml})$ in $35 \mathrm{~mm}$ culture dishes. The culture density was $\sim 50,000$ cells $/ \mathrm{cm}^{2}$. The culture medium contained minimal essential medium (Life Technologies, Gaithersburg, MD) supplemented with $10 \%$ fetal calf serum (HyClone, Logan, UT) and Serum Extender (Collaborative Research, Bedford, MA), 100 U/ml penicillin/streptomycin, and $6 \mathrm{gm} / 1$ glucose. The cultured cells were maintained in an incubator at $37^{\circ} \mathrm{C}$ and $5 \% \mathrm{CO}_{2}$ for up to 4 weeks and fed twice weekly. Cytosine arabinoside $(5 \mu \mathrm{M})$ was added to cultures after $2 \mathrm{~d}$ of plating to inhibit the proliferation of astrocytes.

Microculture. Most steps in the formation of microcultures were similar to those described for the above multicellular cultures. The main differences were that the coverslips were specially treated and the total plating density was very low. The coating of the cover glass is a modification of previous methods (Furshpan et al., 1986; Bekkers and Stevens, 1991; Johnson, 1994). The $35 \mathrm{~mm}$ coverslips were covered first with a thin layer of $0.15 \%$ agarose solution and allowed to dry. A slide on which a grid of 81 squares (each $1 \times 1 \mathrm{~mm}$ ) had been scratched was used as a template and placed under culture dishes (containing agarose-coated coverslips) to guide the applying of droplets of poly-D-lysine. A micropipette (tip broken to $20-80 \mu \mathrm{m})$, connected with a syringe, was filled with poly-Dlysine solution $(0.5 \mathrm{mg} / \mathrm{ml})$ and used to apply a microdrop of the solution to the center of each grid square on the cover glasses. The water in each microdrop evaporated within a few minutes, and dots of poly-D-lysine, with a diameter of 100-500 $\mu \mathrm{m}$, provided an adhesive substrate for neurons. A very low density of cells $\left(\sim 2000-5000\right.$ cells $\left./ \mathrm{cm}^{2}\right)$ was plated on the cover glasses containing the poly-D-lysine dots. Only those neurons sitting on the poly-D-lysine dots survived. There were usually 1-8 neurons falling on each poly-D-lysine dot after plating. Two weeks later, 3-6 dots (microislands) in each dish contained only a single neuron, usually accompanied by astrocytes confined within the dots. In some microcultures, astrocytes $\left(8000-10,000 / \mathrm{cm}^{2}\right)$ were plated $2 \mathrm{~d}$ before plating neurons onto coverslips containing dots of poly-D-lysine to help neuronal growth. There were no perceptible differences between the microcultures with and without preplated astrocytes, probably because all the surviving neurons in the microcultures without preplated astrocytes also were accompanied by astrocytes coming from the dissociated tissues. Cytosine arabinoside $(5 \mu \mathrm{M})$ was added to cultures on the fourth day of plating neurons (or astrocytes) to arrest astrocyte proliferation. The microcultures were maintained similarly to the mass cultures and fed once weekly. The electrophysiological recording usually was performed in microcultures older than $19 \mathrm{~d}$ in vitro (DIV).

Intracellular labeling and staining. A typical SCN neuron microculture is illustrated in Figure $2 A$. The neuron was filled with $1 \%$ biocytin during whole-cell recording. After filling, cells were fixed in $4 \%$ paraformaldehyde and $0.1 \%$ glutaraldehyde for several hours. Plasma membranes were permeabilized with $0.3 \%$ Triton X-100 and labeled with an avidinhorseradish peroxidase complex (Vector Labs, Burlingame, CA). After washing in PBS, cultures were incubated in diaminobenzidine and hydrogen peroxide until the labeled cells were brown. This reaction product was then intensified with $0.1 \%$ osmium tetroxide for $1 \mathrm{~min}$. Cells not filled with biocytin showed no color, and labeled cells had a dark brown or black appearance.

\section{Electrophysiological recording}

Whole-cell voltage-clamp and current-clamp recordings were made with an Axoclamp-2B amplifier (Axon Instruments, Foster City, CA) or a List EPC-7 amplifier. Patch pipettes were pulled from thin-wall borosilicate glass (World Precision Instruments, Sarasota, FL). The pipette resistance after filling with the electrode solution was 4-6 M $\Omega$. The seal resistance was $\sim 10 \mathrm{G} \Omega$ after forming a tight seal. The series resistance after breaking through the tip membrane patch was $15-28 \mathrm{M} \Omega$ and partially (40-60\%) compensated by the amplifier. Data were acquired with AxoData software (Axon Instruments) and processed by Axograph software (Axon Instruments) and Igor Pro software (WaveMetrics) on an Apple Macintosh computer. The data sampling rate was $1-10 \mathrm{kHz}$, filtered at 1 $\mathrm{kHz}$ by an 8-pole Bessell filter (Frequency Devices, Haverhill, MA). The presynaptic release in an autaptic neuron was evoked by a brief positive current injection $(2 \mathrm{msec}, 10-40 \mathrm{pA})$ in current-clamp mode or a voltage pulse $(2 \mathrm{msec}, 60-70 \mathrm{mV})$ in voltage-clamp mode. In some voltage-clamp experiments, the capacitance current induced by the brief voltage pulse was subtracted by using $\mathrm{P} / 4$ protocol (see below). The postsynaptic GABA response was evoked by a brief pressure ejection of GABA (50 $\mu \mathrm{M}, 50 \mathrm{msec}, 4-7.5 \mathrm{psi})$, through a micropipette (2-3 $\mu \mathrm{m}$ tip diameter) connected to a pneumatic microinjector (Narishige USA, Greenvale, NY) under computer control. The recording chamber was perfused constantly by bath solution at a rate of $1.5-2 \mathrm{ml} / \mathrm{min}$. NPY, its analogs, and bicuculline were applied mainly through a series of glass flow pipes (400 $\mu \mathrm{m}$ inner diameter) fed by gravity. Alternatively, these drugs occasionally were applied by adding them to the perfusing solution. Experiments were performed at room temperature $\left(22^{\circ} \mathrm{C}\right)$, as done in previous studies (Bekkers and Stevens, 1991; Tong et al., 1996). The data are reported as mean \pm SEM, and paired Student's $t$ tests were used in comparing two groups of data.

\section{Solutions}

The standard bath solution contained (in $\mathrm{mm}$ ): $162.5 \mathrm{NaCl}, 2.5 \mathrm{KCl}, 2$ $\mathrm{CaCl}_{2}, 10$ HEPES, and 10 glucose, $\mathrm{pH}$ 7.3. TTX $(1 \mu \mathrm{M})$ and AP5 (100 $\mu \mathrm{M}) / \mathrm{CNQX}(10 \mu \mathrm{M})$ were added into bath solution when spontaneous GABA activity was recorded. Two types of pipette solutions were used to record GABA-mediated events (spontaneous or evoked). One contained (in mM): $145 \mathrm{KMeSO}_{4}, 1 \mathrm{MgCl}_{2}, 10 \mathrm{HEPES}, 2 \mathrm{~K}_{4}$-BAPTA, $4 \mathrm{Mg}$-ATP, and $0.5 \mathrm{Na}_{2}-\mathrm{GTP}, \mathrm{pH}$ 7.3. When this pipette solution is used, the reversal potential for $\mathrm{GABA}$-gated $\mathrm{Cl}^{-}$channels is more negative than the resting membrane potential and resulted in the normal direction of IPSPs or 
A

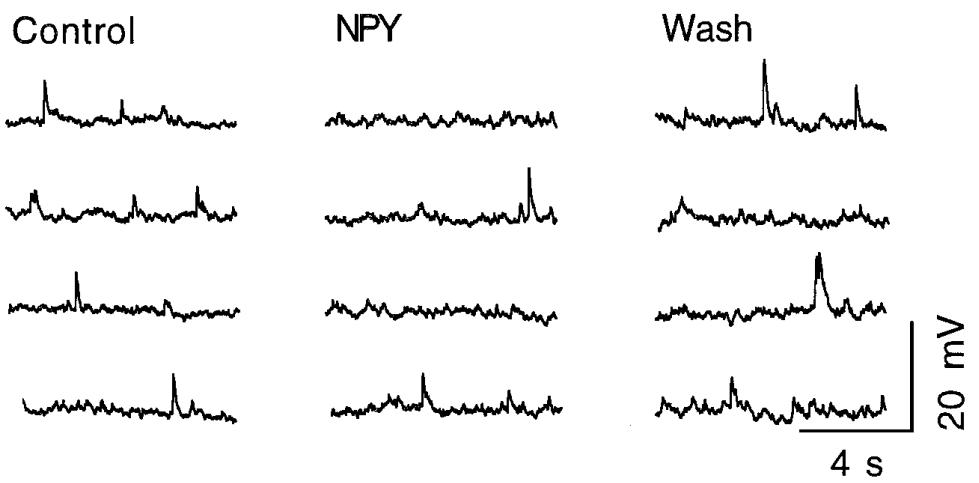

2

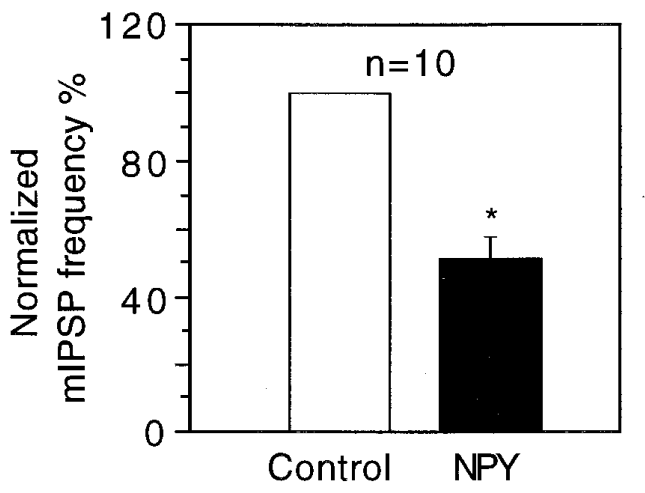

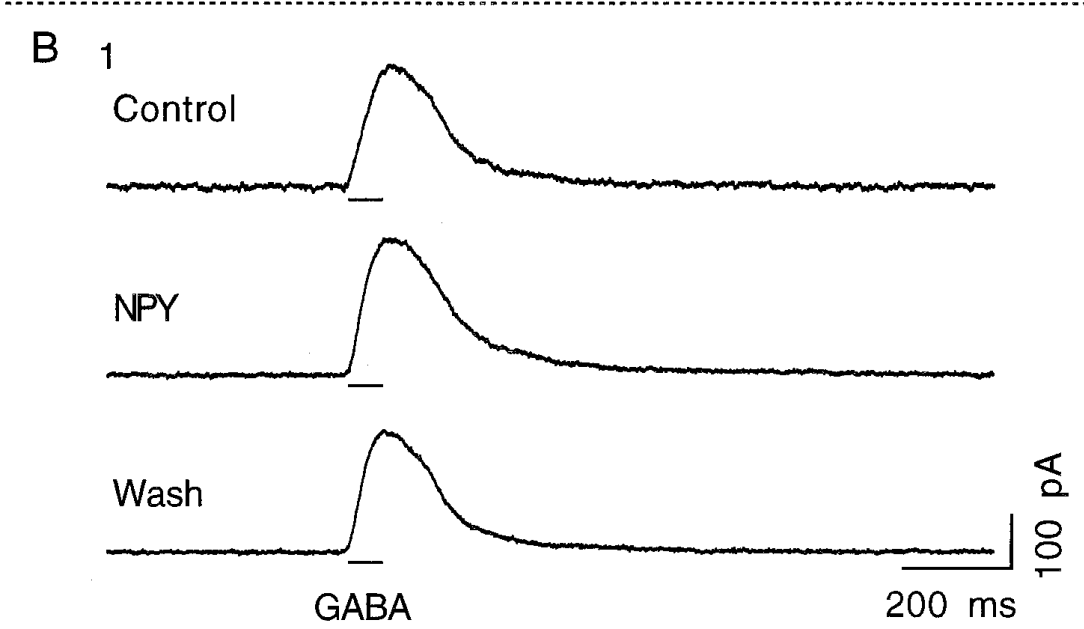

2

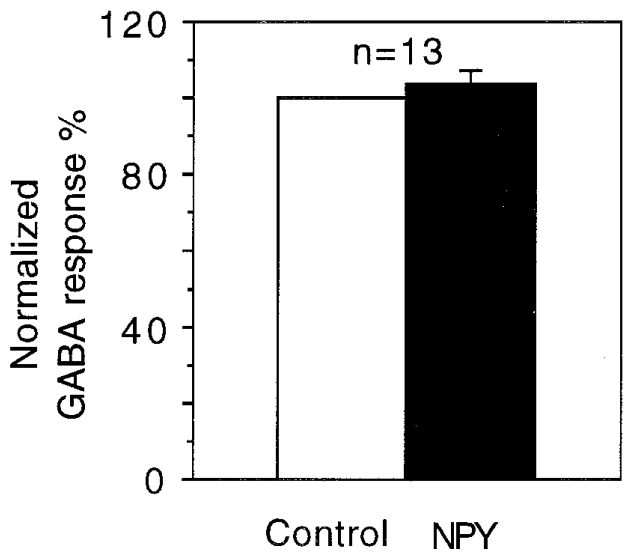

Figure 1. NPY reduces mIPSP frequency but has little effect on postsynaptic GABA responses. $A 1$, Consecutive traces showing that NPY (80 nM) reduced the miniature inhibitory postsynaptic potentials (mIPSPs) in the presence of TTX (1 $\mu \mathrm{M})$ and glutamate receptor antagonists AP5 (100 $\mu \mathrm{M})$ and CNQX $(10 \mu \mathrm{M})$. The upward IPSPs are attributable to a KCl-based pipette solution. $A 2$, Quantification indicating that NPY depressed the mIPSP frequency to approximately one-half of the control $(p<0.01) . B$, NPY has little effect on postsynaptic GABA responses. B1, Pressure-ejected (5 psi, 50 $\mu \mathrm{M})$ GABA-induced postsynaptic responses before, during, and after the application of NPY (200 nM). B2, Quantitative illustration of the null effect of NPY on postsynaptic GABA responses $(p>0.1)$.

IPSCs. The other pipette solution contained (in $\mathrm{mM}$ ): $145 \mathrm{KCl}, 10$ HEPES, $2 \mathrm{~K}_{4}$-BAPTA, $4 \mathrm{Mg}$-ATP, and $0.5 \mathrm{Na}_{2}$-GTP, pH 7.3. With this pipette solution, the reversal potential for GABA-gated $\mathrm{Cl}^{-}$channels is close to $0 \mathrm{mV}$ and resulted in an opposite direction of IPSPs or IPSCs to the normal direction. The advantage of the KCl-based pipette solution is to provide a greater driving force for the GABA-gated $\mathrm{Cl}^{-}$channels and increase the amplitude of recorded IPSPs or IPSCs. For the recording of whole-cell barium currents, the bath solution contained (in $\mathrm{mM}$ ): 114.5 $\mathrm{NaCl}, 40 \mathrm{TEA}-\mathrm{Cl}, 2.5 \mathrm{KCl}, 5 \mathrm{BaCl}_{2}, 10 \mathrm{HEPES}$, and 10 glucose plus $1 \mu \mathrm{M}$ TTX, pH 7.3; the pipette solution contained $135 \mathrm{CsCl}, 2 \mathrm{~K}_{4}$-BAPTA, 10 HEPES, 4 Mg-ATP, $0.5 \mathrm{Na}_{2}$-GTP, and 10 creatine phosphate, plus 50 $\mathrm{IU} / \mathrm{ml}$ creatine phosphokinase, $\mathrm{pH}$ 7.3. The sodium and potassium currents were blocked by TTX and the combination of TEA ${ }^{+}, \mathrm{Ba}^{2+}$, and $\mathrm{Cs}^{+}$. The leak current and the capacitance current were subtracted by a $\mathrm{P} / 4$ protocol, i.e., four subpulses with opposite direction and $1 / 4$ amplitude of the main command voltage pulse were applied to induce leak and capacitance currents and then subtracted from the main evoked current.

\section{Pharmacological agents}

GABA, (-)-bicuculline methiodide (BIC), D,L-2-amino-5-phosphonopentanoic acid (AP5), cyano-2,3-dihydroxy-7-nitroquinoxaline (CNQX), tetrodotoxin (TTX), tetraethylammonium hydrochloride (TEA-Cl), Mg-ATP, phosphocreatine, and phosphocreatine kinase were purchased from Sigma (St. Louis, MO). Neuropeptide Y (NPY, porcine), $\left[\mathrm{Leu}^{31}, \mathrm{Pro}^{34}\right]-\mathrm{NPY}$, NPY 13-36, and PYY were obtained from Peninsula Labs (Belmont, CA).

\section{RESULTS}

\section{NPY inhibits GABAergic spontaneous activity}

Although NPY has been found to inhibit noradrenergic, acetylcholinergic, and glutamatergic neurotransmission in some neuronal systems, direct evidence of NPY modulation of GABA, the most important inhibitory transmitter in the CNS, is lacking. In cultured SCN neurons, inhibitory GABAergic events dominated spontaneous activity. NPY ( $80 \mathrm{~nm}, 2-4 \mathrm{~min})$ substantially inhibited the GABA-mediated spontaneous activity, as shown in Figure $1 A$. Four successive traces in each condition of control, NPY application, and after wash are displayed in Figure 1A1. The frequency, but not the amplitude, of spontaneous events was reduced significantly by NPY, and the inhibition was reversible. TTX $(1 \mu \mathrm{M})$ was maintained in the bath solution to prevent action potential-dependent release of GABA. Glutamate receptor antagonists AP5 $(100 \mu \mathrm{M})$ and CNQX $(10 \mu \mathrm{M})$ also were included in the bath solution to abolish excitatory events. The spontaneous GABAergic events are upward in the current-clamp mode because of the KCl-based pipette solution, and all of these events were blocked by bicuculline $(30 \mu \mathrm{M}), \mathrm{GABA}_{\mathrm{A}}$ receptor antagonist (see Fig. 4). Data from 10 neurons examined are summarized in Figure 1A2. NPY ( $80 \mathrm{~nm})$ reduced the frequency of 
spontaneous activity to $51.5 \pm 6.1 \%$ of the control $(p<0.01$, paired $t$ test) with little effect on the amplitude of the spontaneous events, suggesting a presynaptic mechanism of the NPY action. In 4 of 10 neurons, the reduction of the frequency of spontaneous activity showed continuing recovery, but not full recovery, after 20 min of buffer rinse of NPY. Although long-term experiments were beyond the scope of the current work, these preliminary observations were consistent with our previous finding in immature SCN neurons that NPY may have exerted long-lasting effects on GABA release (Obrietan and van den Pol, 1996).

To address directly the question of whether NPY inhibited the postsynaptic GABA receptors, we used a pneumatic microinjector to pressure-eject GABA $(50 \mu \mathrm{M})$ onto neurons through a micropipette (2-3 $\mu \mathrm{m}$ tip). A typical example is illustrated in Figure $1 B$. NPY (200 nM) applied for $\sim 2$ min had little effect on the GABAevoked postsynaptic responses (Fig. 1B1). Data shown in Figure $1 B 2$ are from all 13 neurons examined. NPY had no consistent effect on postsynaptic GABA receptor responses. In 4 of 13 neurons, we observed an increase of $\sim 20 \%$, rather than a decrease, in the GABA response after NPY application, whereas in three neurons there was a $10-13 \%$ decrease of the GABA response after NPY application. In the other six neurons, the GABA responses were not affected by NPY. Together, after normalizing the control response as $100 \%$, the relative response to GABA in the presence of NPY was $103.7 \pm 3.5 \%$, not significantly different from the control $(p>0.1)$. This indicates that NPY inhibits the GABA neurotransmission of SCN neurons mainly via a presynaptic mechanism.

The effect of NPY on cell input resistance was examined by injecting a series of current pulses to evoke a series of voltage changes in the current-clamp mode. In eight neurons tested, NPY (80-200 nM) had little effect on the cell input resistance. The average cell input resistance before and during NPY application was $1.3 \pm 0.2$ and $1.2 \pm 0.2 \mathrm{G} \Omega$, respectively. The effect of NPY on the resting membrane potential was examined also. In 11 neurons tested, NPY (80-200 nM) slightly hyperpolarized 8 neurons, depolarized 2 neurons, and had no effect on 1 neuron. The average resting potentials before and after NPY application were $-58.0 \pm 1.6$ and $-59.7 \pm 1.7 \mathrm{mV}$, respectively.

\section{Presynaptic inhibition of NPY on autaptic GABA release}

Previous studies on the mechanism of NPY action were performed in mass cell cultures or brain slices (Wahlestedt et al., 1986; Walker et al., 1988; Colmers et al., 1991; Bleakman et al., 1992; Simonneaux et al., 1994; Obrietan and van den Pol, 1996). Because results were obtained from a net of many neurons, it is difficult to know how NPY acts on a single neuron and whether NPY Y1 and Y2 subtype receptors cofunction in the same neuron. The present study used single-neuron microcultures in which a single neuron in a microisland formed synapses with itself. In our single-neuron microcultures of SCN cells, 47 neurons showing autaptic responses were GABAergic and only 4 neurons were not, confirming that the majority of SCN neurons are GABAergic. Figure $2 A$ shows a typical single autaptic $\mathrm{SCN}$ neuron in a microisland culture, filled with biocytin during electrophysiological recording and fixed and stained with avidin-HRP after the completion of experiments. Traces shown in Figure $2 B, C$ are electrical responses recorded from the illustrated neuron. The neuron was current-clamped, and a brief positive current injection (20 pA, $2 \mathrm{msec}$ ) invariably evoked a single action potential, followed by a large evoked IPSP (Fig. $2 \mathrm{~B}$, control trace). The IPSP was reversibly blocked by $30 \mu \mathrm{M}$ bicuculline (BIC, Fig. $2 B$, middle trace), indicating its GABAergic origin. Figure $2 C$ shows that NPY (200 nM) reversibly blocked the GABAergic IPSP. In the presence of NPY, the large IPSP that follows the action potential was totally eliminated. Similarly, NPY (200 nM) totally blocked the evoked GABA response in another two autaptic neurons and, in a fourth neuron, reduced the autaptic GABA response to $28 \%$ of the control. In only one neuron tested did NPY have no effect on the evoked autaptic response. Thus, NPY strongly inhibits presynaptic GABA release in single SCN neurons.

A traditional way to identify a presynaptic versus a postsynaptic effect of a chemical is to examine its effect on the frequency of miniature spontaneous activity and postsynaptic responses, as illustrated in Figure 1. In studying the mechanism of NPY action, we found that single-neuron microcultures are ideal for discriminating a presynaptic versus a postsynaptic effect of neurotransmitters or neuromodulators. Figure 3 illustrates such a scenario, in which a presynaptic and/or a postsynaptic effect are evident concurrently after a single application of NPY. Autaptic transmitter release was evoked by a brief voltage pulse $(2 \mathrm{msec}, 60 \mathrm{mV})$ under voltage-clamp (holding potential $=-60 \mathrm{mV}$ ) condition. A postsynaptic response was evoked by a brief pressure ejection (50 msec, 5 psi) of $50 \mu \mathrm{M}$ GABA onto the recording neuron under computer control. Figure $3 A$ shows both an evoked autaptic response and a postsynaptic GABA response in the same sweep. In Figure 3B, NPY (200 nM) abolished the presynaptic response while leaving the postsynaptic response unaffected. The box in Figure $3 B$ demonstrates that the sodium action current was not blocked by NPY. Figure $3 C$ illustrates that the NPY inhibition is reversible. In Figure $3 D$, bicuculline $(30 \mu \mathrm{M})$ blocked both the pre- and postsynaptic responses, indicating that both are mediated by $\mathrm{GABA}_{\mathrm{A}}$ receptors. Similar results were obtained in two other single autaptic neurons. This is the first time that NPY has been demonstrated to inhibit synaptic neurotransmission by acting only presynaptically, but not on postsynaptic receptors in a single neuron.

\section{Both NPY Y1- and Y2-like receptors coexist in the same SCN neuron}

A further question regarding presynaptic NPY inhibition is, through which subtype NPY receptor does NPY act? We pursued this question initially by examining the effect of NPY Y1 and Y2 receptor agonists on the miniature spontaneous activity in multicelled cultures. Although recent evidence has revealed several NPY receptors, they have differential sensitivities to activation by $\left[\mathrm{Leu}^{31}, \mathrm{Pro}^{34}\right]$-NPY (Y1-like: Y1, Y4, Y5) and NPY13-36 (Y2like: Y2). Y5m and Y5r show greater sensitivity to [ $\left.\mathrm{Leu}^{31}, \mathrm{Pro}^{34}\right]-$ NPY but also respond weakly to NPY13-36 (Gerald et al., 1996; Weinberg et al., 1996). As in the experiments shown in Figure $1 A$, TTX and AP5/CNQX were included in the bath solution to prevent action potential-mediated release of transmitters and to block glutamate receptors. Figure $4 A-E$ shows a typical example of the effect of Y1 agonist $\left[\mathrm{Leu}^{31}, \mathrm{Pro}^{34}\right]-\mathrm{NPY}(80 \mathrm{nM})$ and Y2 agonist NPY 13-36 (80 nM) on the spontaneous activity. Both agonists reduced the frequency, but not the amplitude, of the spontaneous events, and for both the inhibition were reversible. Bicuculline eliminated all the spontaneous events, indicating their GABAergic properties. The spontaneous events were inward in voltage clamp because of the use of a $\mathrm{KCl}$-based pipette solution. The general effect of $\mathrm{Y} 1$ and $\mathrm{Y} 2$ receptor agonists is summarized in Figure $4 F$. By normalizing the frequency of the spontaneous activity in the control condition to $100 \%,\left[\mathrm{Leu}^{31}, \mathrm{Pro}^{34}\right]-\mathrm{NPY}$ (80 

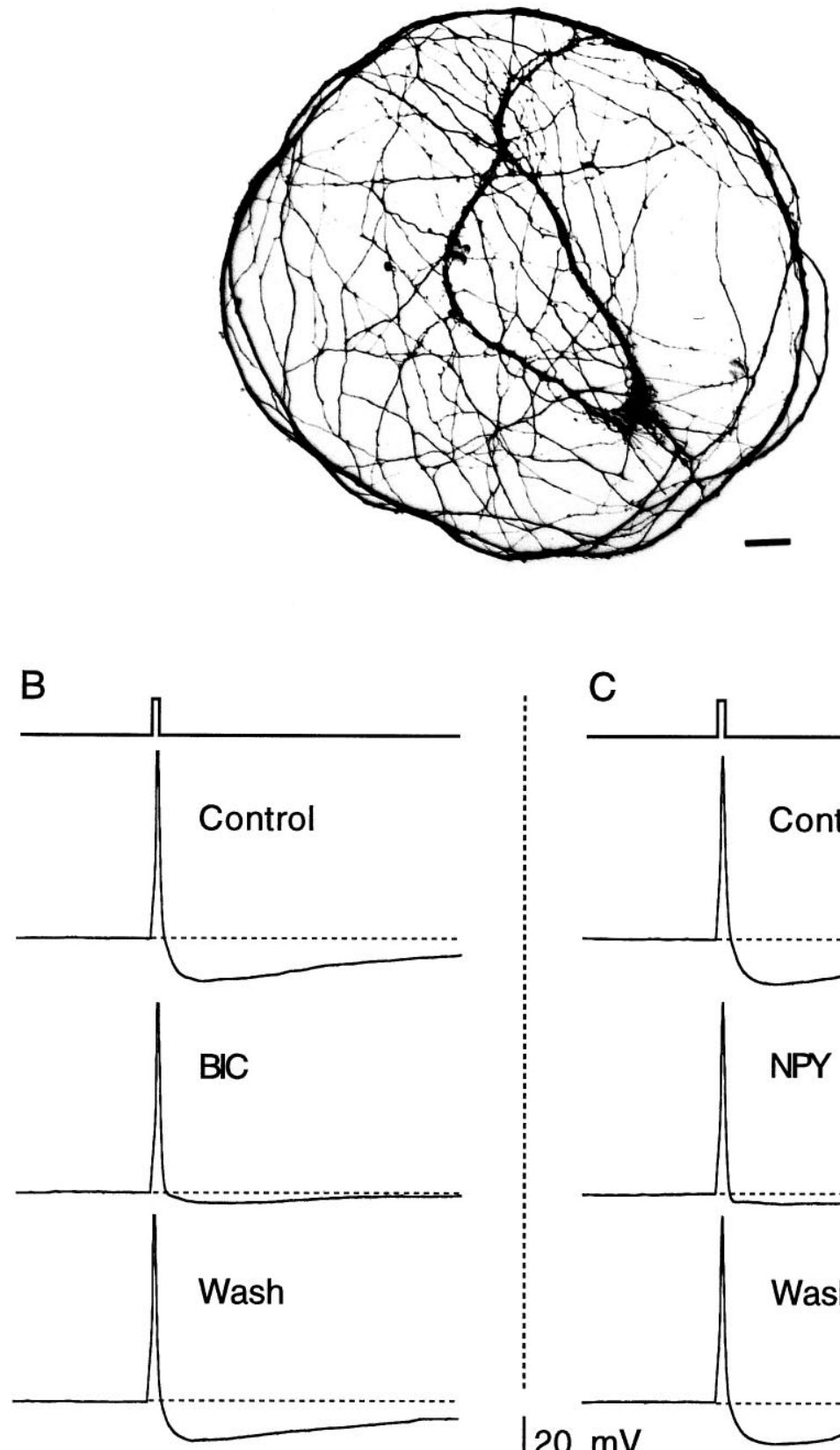

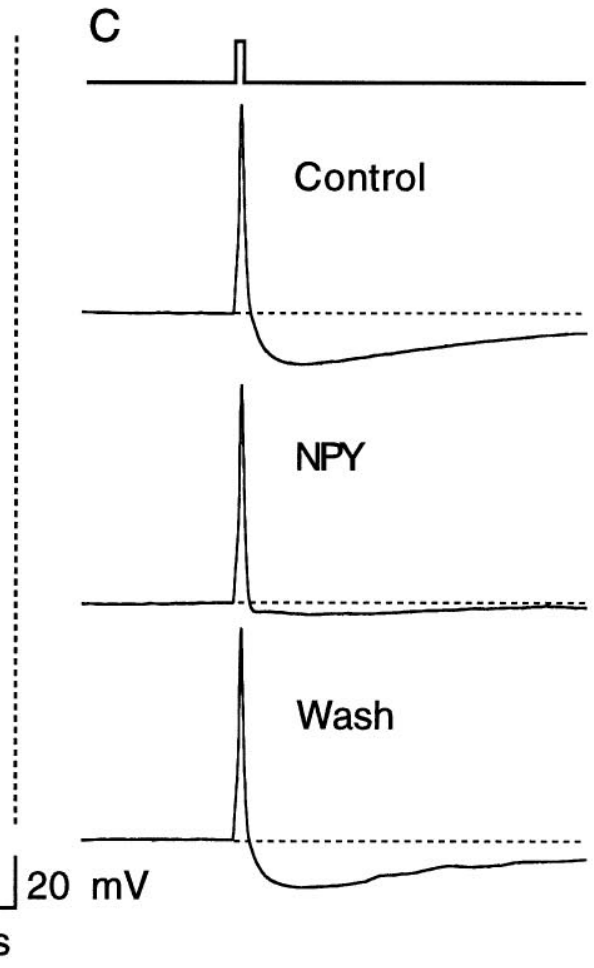

Figure 2. NPY reversibly blocks the evoked autaptic GABA release in single-neuron microcultures. $A$, A single $\mathrm{SCN}$ neuron in a microisland culture. The neuron was filled by biocytin during whole-cell recording and stained with avidin-HRP. $B, C$, Action potentials and the following autaptic IPSPs initiated by a brief current injection $(2 \mathrm{msec}$, $20 \mathrm{pA}$ ) recorded in the single neuron illustrated in $A$. $B$, The evoked autaptic IPSP was reversibly blocked by bicuculline $(B I C, 30 \mu \mathrm{M})$. C , The evoked autaptic IPSP also was reversibly blocked by NPY (200 nM).
$\mathrm{nM})$ reduced the frequency to $59.3 \pm 5.5 \%$ of the control $(p<$ $0.01, n=11)$, and NPY $13-36(80 \mathrm{nM})$ reduced the frequency to $57.4 \pm 9 \%$ of the control $(p<0.05, n=10)$. For both agonists the inhibition was significant and reversible. These experiments demonstrate that NPY inhibits the GABA neurotransmission in SCN neurons through both Y1- and Y2-like receptors.

The above experiments on multicellular cultures demonstrated that both NPY Y1- and Y2-like receptors are involved in the action of NPY on SCN cells. However, whether the two subtype receptors coexist in the same neuron or are distributed among different neurons was not clear. A single-neuron microculture provides an opportunity to study the distribution of Y1- and Y2-like receptors in single neurons. In total, 30 single autaptic neurons were examined to study the effect of $\left[\mathrm{Leu}^{31}, \mathrm{Pro}^{34}\right]-\mathrm{NPY}$ (80 nM) and NPY 13-36 (80 nM) on the evoked autaptic responses. In all, 9 of 30 neurons showed no reduction or $<10 \%$ reduction in the evoked responses by both agonists. Different neurons showed different sensitivity to Y1 and Y2 agonists. [ $\left.\mathrm{Leu}^{31}, \mathrm{Pro}^{34}\right]-\mathrm{NPY}$ reduced the evoked response by up to $88 \%$, and NPY 13-36 reduced the response by up to $84 \%$. Some neurons were more sensitive to the Y1 agonist and less sensitive to the Y2 agonist, some showed the opposite response, and some were equally sensitive to both agonists. The sequential application of Y1 and Y2 agonists was random among neurons. Some neurons were given the $\mathrm{Y} 1$ agonist first and then the $\mathrm{Y} 2$ agonist, and in others the opposite procedure was used. In most cases, the first applica- 
$\begin{array}{ll}\text { Presynaptic Postsynaptic } & \end{array}$
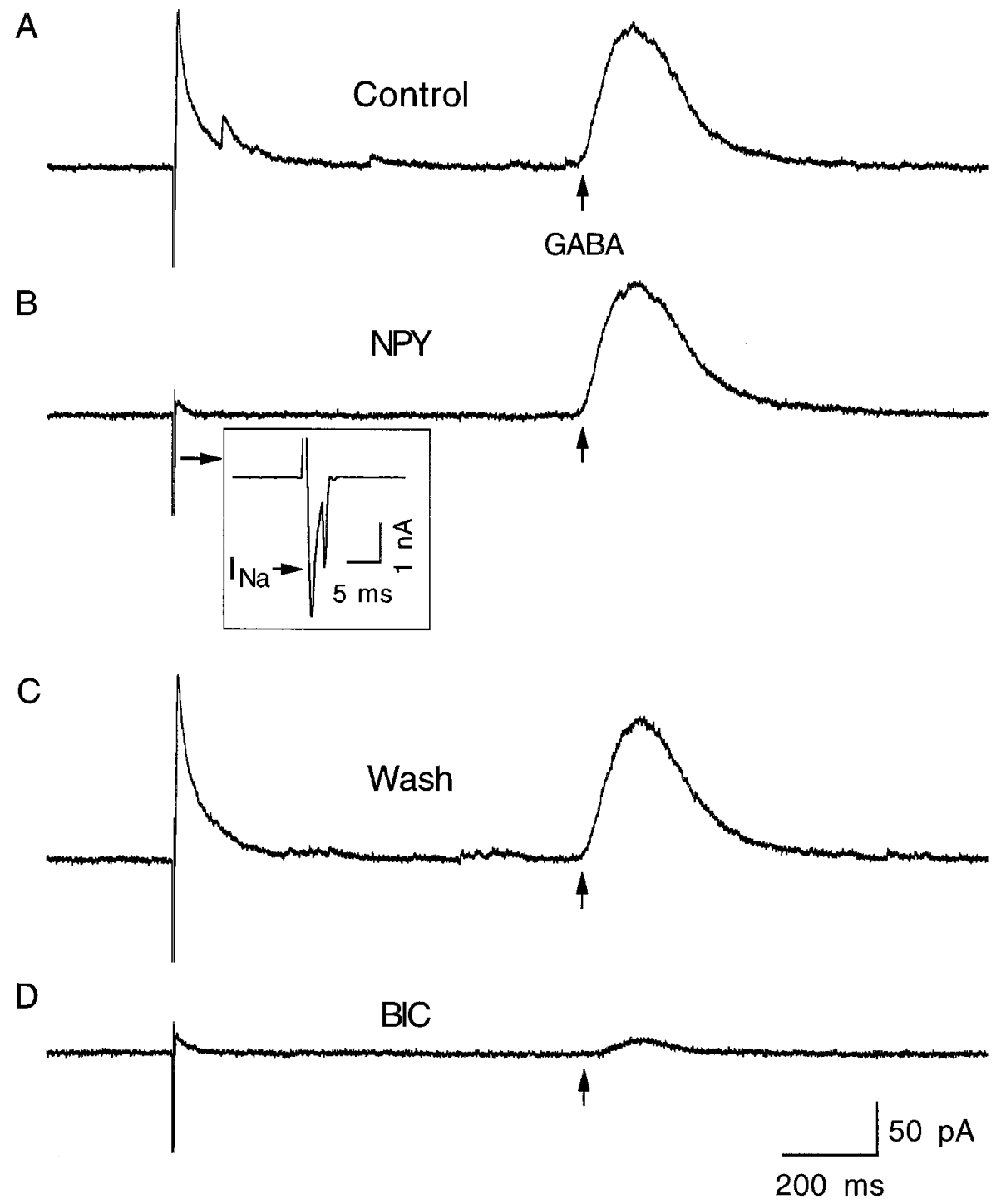

Figure 3. NPY inhibits presynaptic GABA release, but not the postsynaptic GABA response, in the same autaptic SCN neuron. A, Presynaptically released GABA (triggered by $2 \mathrm{msec}, 60$ $\mathrm{mV}$ voltage pulse) induced IPSC and pressureejected GABA-evoked response in the same recording. $B$, NPY (200 nM) eliminated the presynaptic release but did not affect the postsynaptic response. The box shows the sodium action current in the presence of NPY. $C$, The inhibition of NPY on presynaptic release was reversible. $D$, Bicuculline abolished both the pre- and the postsynaptic GABA responses. Capacitance currents and action currents were truncated. ity of a significant involvement in these neurons of a putative Y3 subtype of NPY receptor that is insensitive to PYY (Colmers and Bleakman, 1994).

\section{Inhibition of whole-cell barium currents}

Previous studies suggest that an inhibition of calcium currents may underlie the inhibition of synaptic transmitter release (Colmers et al., 1988; Walker et al., 1988; Toth et al., 1993). We therefore explored whether the inhibition of NPY on GABA neurotransmission was mediated by an inhibition of calcium currents in SCN neurons and whether Y1- or Y2-like receptors were involved in the inhibition of the calcium currents. The recorded neurons were held at $-80 \mathrm{mV}$, and a command pulse $(80 \mathrm{mV}, 40$ $\mathrm{msec}$ ) was applied to evoke a barium current (through voltageactivated calcium channels). As in the effect on the autaptic release, both $\mathrm{Y} 1$ and $\mathrm{Y} 2$ agonists were found to inhibit the whole-cell barium currents $\left(I_{\mathrm{Ba}}\right)$ in SCN neurons. Also similar to the autaptic release, Y1 and Y2 agonists produced different inhibition of $I_{\mathrm{Ba}}$ in different individual neurons. A typical example of the effect of both agonists in the same neuron is shown in Figure 
A Control

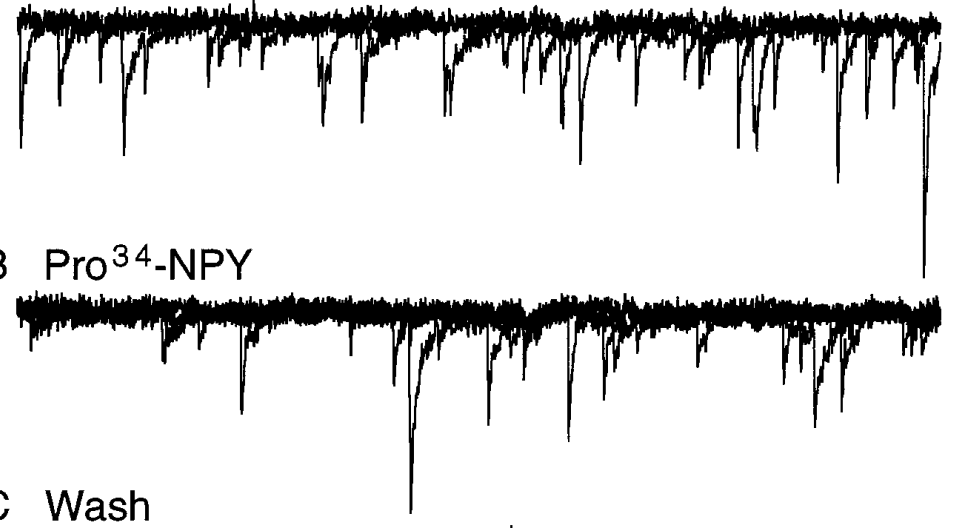

C Wash

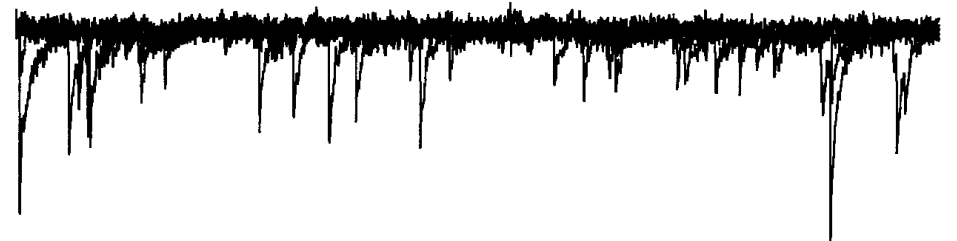

D NPY 13-36

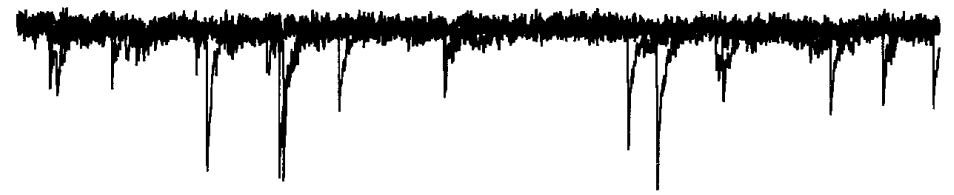

E Bicuculline

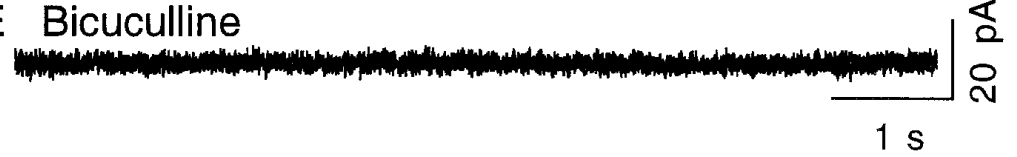

F

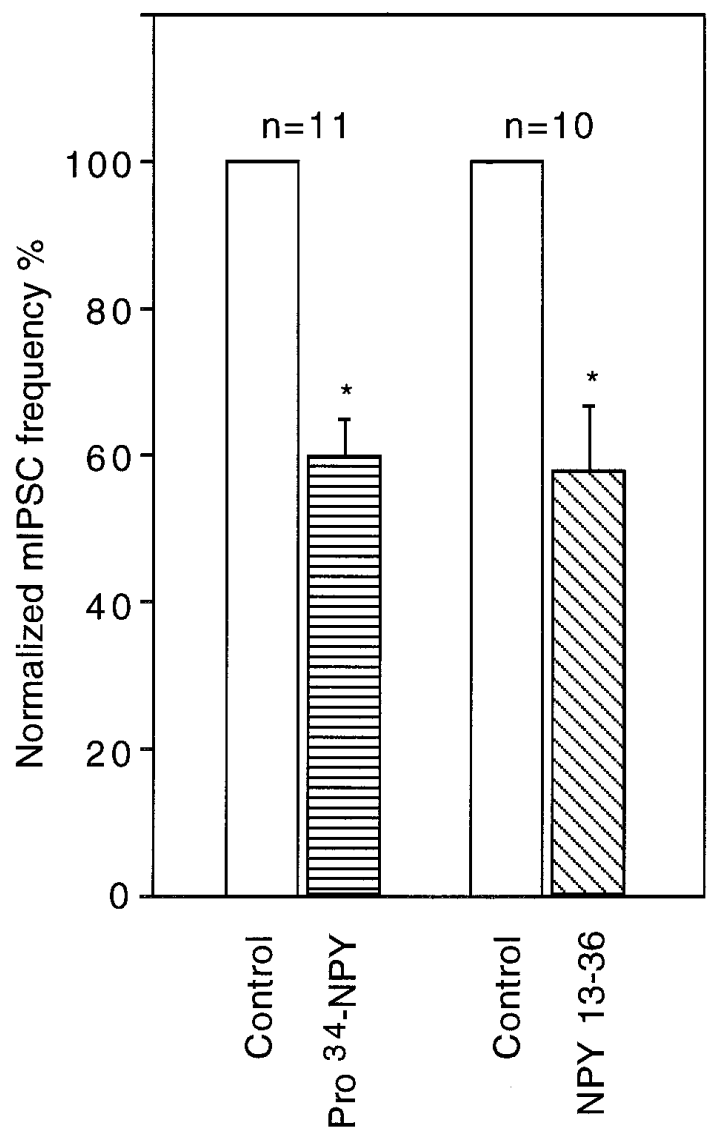

Figure 4. Both NPY Y1- and Y2-like receptors mediate the inhibition of miniature spontaneous GABA activity. $A$, Superimposed four consecutive traces illustrating control mIPSCs in the presence of TTX and AP5/CNQX. $B$, NPY Y1 receptor agonist, [Leu ${ }^{31}$, Pro $\left.{ }^{34}\right]$-NPY (80 nM) reduced the mIPSC frequency. $C$, The inhibition of [ $\left.\mathrm{Leu}^{31}, \mathrm{Pro}^{34}\right]$-NPY was reversible. $D$, NPY Y2 receptor agonist NPY $13-36$ (80 nM) also reduced the mIPSC frequency recorded from the same neuron. $E$, All of the mIPSCs were abolished by $30 \mu \mathrm{M}$ bicuculline. $F$, Quantitative analysis showing that both $\left[\mathrm{Leu}^{31}\right.$, Pro $\left.{ }^{34}\right]$-NPY and NPY 13-36 significantly reduced the mIPSC frequency to $<60 \%$ of the control.

6. $A 1$ shows that NPY 13-36 substantially suppressed the $I_{\mathrm{Ba}}$, and the suppression was reversible. $B 1$ shows that in the same neuron $\left[\mathrm{Leu}^{31}, \mathrm{Pro}^{34}\right]-\mathrm{NPY}$ also reversibly inhibited the $I_{\mathrm{Ba}}$, although much less than did NPY 13-36. $A 2$ and $B 2$ illustrate the $I-V$ curves of $I_{\mathrm{Ba}}$ before and after the application of NPY 13-36 and [Leu ${ }^{31}$, Pro $\left.^{34}\right]$-NPY. Except for the reduction of $I_{\mathrm{Ba}}$ by both agonists, the shape of the $I-V$ curves was not changed by either NPY 13-36 or $\left[\mathrm{Leu}^{31}, \mathrm{Pro}^{34}\right]-\mathrm{NPY}$. The potential at which the $I_{\mathrm{Ba}}$ reached the peak was $\sim 0 \mathrm{mV}$, and the reversal potential for $I_{\mathrm{Ba}}$ was approximately $+50 \mathrm{mV}$, not altered by NPY 13-36 and $\left[\mathrm{Leu}^{31}, \mathrm{Pro}^{34}\right]-$ NPY. Figure $7 A$ illustrates the typical time course of the action of NPY 13-36 and $\left[\mathrm{Leu}^{31}\right.$, Pro $\left.{ }^{34}\right]-\mathrm{NPY}$ on the $I_{\mathrm{Ba}}$. The $I_{\mathrm{Ba}}$ was reduced within $20 \mathrm{sec}$ of the application of either agonist. In this particular neuron, in contrast to the one shown in Figure 6, $\left[\mathrm{Leu}^{31}, \mathrm{Pro}^{34}\right]$-NPY produced a greater inhibition than NPY 13-36. The inhibitory effect usually was washed out within $1-2$ min, faster than the recovery of the evoked release. $\mathrm{CdCl}_{2}(100$ $\mu \mathrm{M})$ reversibly abolished the $I_{\mathrm{Ba}}(n=4)$. The overall reduction of $I_{\mathrm{Ba}}$ by NPY 13-36 (80 nM) and [ $\mathrm{Leu}^{31}$, Pro $\left.^{34}\right]$-NPY (80 nM) and by NPY (80 nM) and PYY (80 $\mathrm{nm})$ is summarized in Figure $7 B$. NPY reduced the $I_{\mathrm{Ba}}$ by $32.9 \pm 7.3 \%(p<0.02 ; n=7)$. [Leu ${ }^{31}$, Pro $\left.^{34}\right]$-NPY reduced the $I_{\mathrm{Ba}}$ by $42.6 \pm 7.1 \%(p<0.001 ; n=18)$. NPY 13-36 reduced the $I_{\mathrm{Ba}}$ by $36.7 \pm 7.2 \%(p<0.001 ; n=17)$.
PYY reduced the $I_{\mathrm{Ba}}$ by $23.2 \pm 5.1 \%(p<0.01 ; n=5)$. All 36 neurons (9-30 DIV) examined showed a reduction in the $I_{\mathrm{Ba}}$ by NPY or its analogs, confirming a robust expression of NPY receptors, including both Y1- and Y2-like receptors, in SCN neurons. No developmental changes in NPY inhibition of $I_{\mathrm{Ba}}$ and GABA release were observed in cultured neurons examined.

\section{Inhibition of IPSC and $I_{\mathrm{Ba}}$ in the same $S C N$ neuron}

Because both the presynaptic release and the whole-cell barium currents were inhibited by Y1- and Y2-like receptor agonists, a logical question is whether there is any correlation between these two inhibitory actions. We therefore examined the effect of NPY analogs on both the evoked release and the barium currents in the same self-innervating neuron. Figure 8 shows the results of one such experiment. The effect of $\left[\mathrm{Leu}^{31}, \mathrm{Pro}^{34}\right]-\mathrm{NPY}(80 \mathrm{nM})$ and NPY 13-36 (80 nM) was examined first on the evoked IPSCs and then on the $I_{\mathrm{Ba}}$. Figure $8 \mathrm{~A}$ illustrates the recording traces of the evoked IPSCs and the $I_{\mathrm{Ba}}$, corresponding to those points specified in Figure $8 B$. Both the evoked IPSCs and the $I_{\mathrm{Ba}}$ were inhibited by $\left[\mathrm{Leu}^{31}, \mathrm{Pro}^{34}\right]-\mathrm{NPY}$ and NPY 13-36. The relative amount of reduction in the amplitude of the evoked IPSCs by $\left[\mathrm{Leu}^{31}, \mathrm{Pro}^{34}\right]-$ NPY $(-83 \%)$ and NPY 13-36 $(-77 \%)$ correlated with the reduction of $I_{\mathrm{Ba}}(-89 \%$ and $-52 \%$, respectively). The reduction and 
A
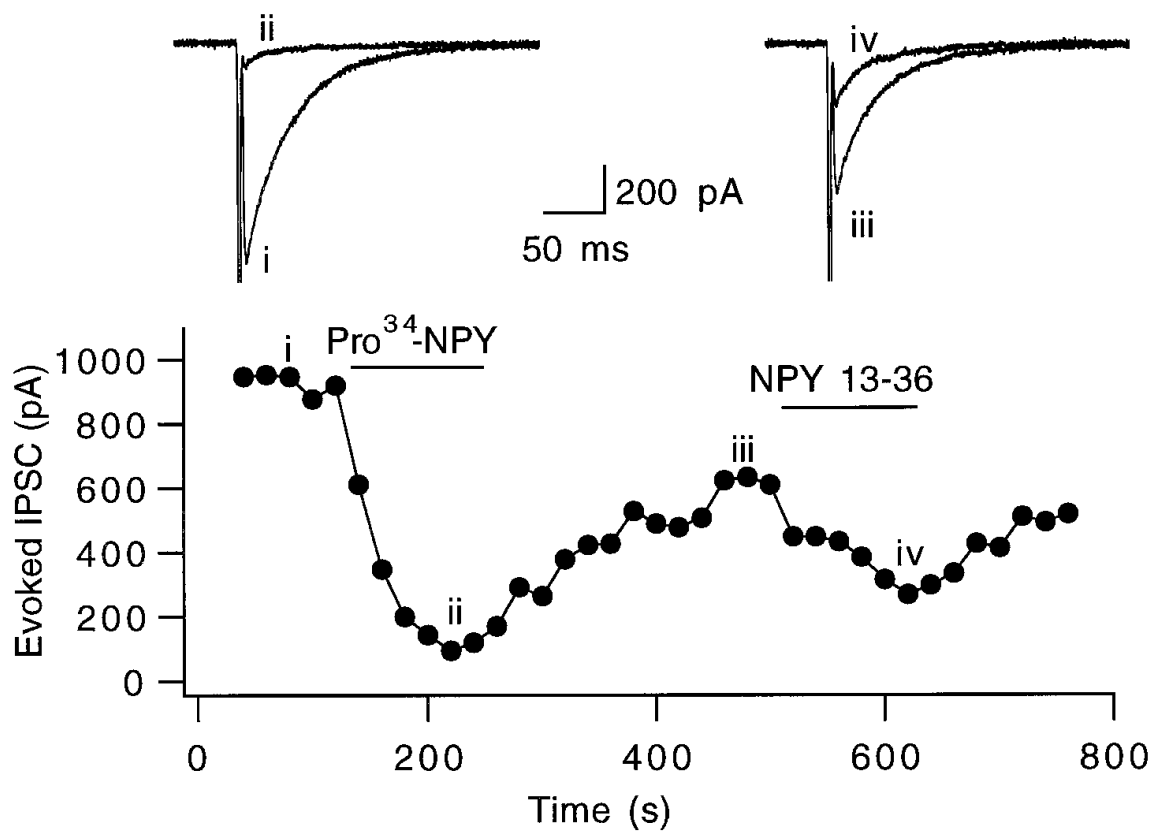

B

Figure 5. NPY Y1 and Y2 agonists both inhibit the evoked autaptic GABA release in the same single SCN neuron. $A$, $\left[\mathrm{Leu}^{31}, \mathrm{Pro}^{34}\right]-$ NPY (80 nM) and NPY 13-36 (80 nM) both substantially inhibited the evoked autaptic IPSC. The recording traces on the top panel correspond to the four points $(i, i i, i i i, i v)$ in the graph below. $B$, Group data showing the reduction of the evoked IPSC by NPY, $\left[\mathrm{Leu}^{31}\right.$, Pro $\left.{ }^{34}\right]$-NPY, NPY 13-36, and PYY.

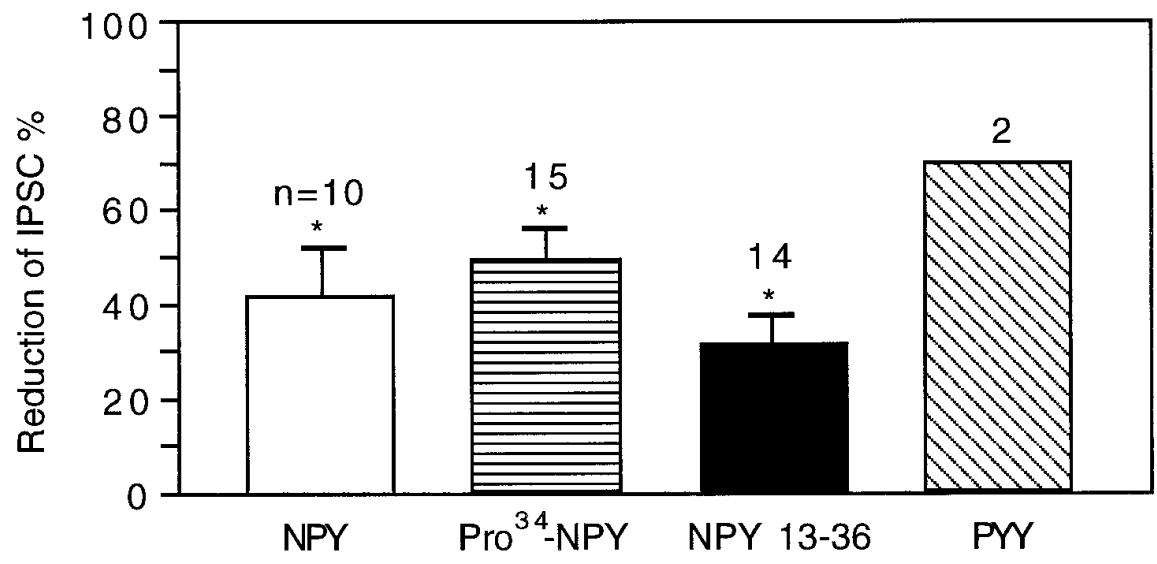

the recovery of $I_{\mathrm{Ba}}$ seemed to be rapid, whereas those of the evoked IPSCs were relatively gradual. Similar results were observed in four other single autaptic neurons on the inhibition of both the evoked IPSCs and the $I_{\mathrm{Ba}}$ by NPY analogs. The overall correlation coefficient between the reduction of IPSCs and $I_{\mathrm{Ba}}$ among the five neurons examined was positive $(r=0.56)$. The recorded whole-cell barium currents were evoked mainly through calcium channels at the cell body. Because of the technical difficulties in using patch pipettes to record directly from single boutons, we cannot directly measure calcium currents at the presynaptic terminals. However, on the working assumption that NPY exerts similar actions in the terminal and perikaryon of the same cell, NPY inhibition of presynaptic GABA release may be mediated by inhibition of calcium channels in the presynaptic nerve terminals.

\section{DISCUSSION}

The present study with SCN neurons provides for the first time direct electrophysiological evidence that NPY modulates inhibitory GABA neurotransmission in the CNS. Studies in other regions of the brain, for instance in hippocampal slices, found that
NPY selectively inhibits excitatory glutamatergic release without a direct effect on GABA release (Klapstein and Colmers, 1993).

\section{Coexistence of NPY Y1- and Y2-like receptors in the same SCN neuron}

The most striking results of the present study are the coexistence of NPY Y1- and Y2-like receptors in both presynaptic axon terminals and postsynaptic neuronal soma of the same GABAergic cell and the demonstration that both Y1- and Y2-like receptors mediate the inhibition of presynaptic GABA release and whole-cell calcium (barium) currents in SCN neurons. These results would not be achieved without the use of single selfinnervating neuron microcultures. Our present study indicates two advantages of such single-neuron microcultures in identifying presynaptic versus postsynaptic effects of neurotransmitters and neuromodulators and in locating and discriminating their (subtype) receptors. Previous studies have indicated that more than one NPY subtype receptor might exist in some preparations. In rat nodose neurons, both $\mathrm{Y} 1$ and $\mathrm{Y} 2$ receptor agonists modulate calcium currents, although with opposite effects (Wiley et al., 1993). In the rat pineal gland, NPY inhibited presynaptic nor- 

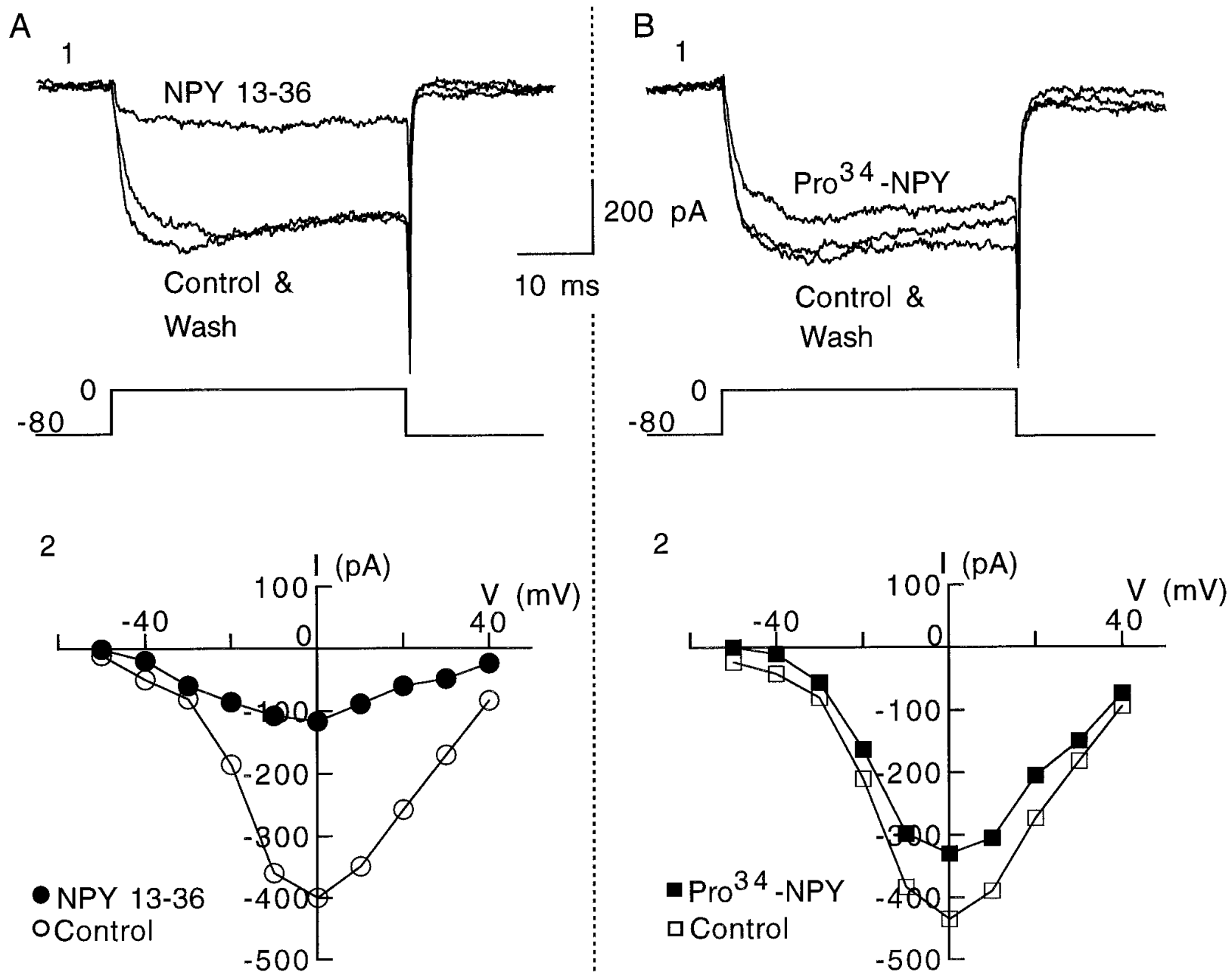

Figure 6. NPY Y1- and Y2-like receptors mediate the inhibition of whole-cell barium currents in the same SCN neuron. $A$, Inhibition by Y2 agonist NPY 13-36 (80 nM). $A 1$, Barium currents $\left(I_{\mathrm{Ba}}\right)$ evoked by test potential from $-80 \mathrm{mV}$ to $0 \mathrm{mV}$ before, during, and after the application of NPY 13-36. $A 2, I-V$ curve of the $I_{\mathrm{Ba}}$ before and during NPY 13-36 application. $B$, Inhibition of $I_{\mathrm{Ba}}$ by Y1 agonist $\left[\mathrm{Leu}^{31}\right.$, Pro $\left.^{34}\right]$-NPY $(80 \mathrm{nM})$ in the same neuron. $B 1, I_{\mathrm{Ba}}$ before, during, and after the application of [Leu ${ }^{31}$, Pro ${ }^{34}$ ]-NPY. B2, I-V curve $I_{\mathrm{Ba}}$ before and during [Leu ${ }^{31}$, Pro ${ }^{34}$-NPY application. Notice that NPY 13-36 produced greater inhibition than $\left[\mathrm{Leu}^{31}, \mathrm{Pro}^{34}\right]-\mathrm{NPY}$ in this neuron. Neither NPY 13-36 nor $\left[\mathrm{Leu}^{31}\right.$, Pro $\left.{ }^{34}\right]$-NPY changed the $I-V$ relationship of the barium currents.

adrenaline release via the activation of $\mathrm{Y} 2$ receptors, but it decreased cyclic AMP elevation induced by $\beta$-adrenaline through a Y1 receptor pathway (Simonneaux et al., 1994), although it is not known whether Y1 and Y2 receptors were in the same cell. In rat dentate granule cells, NPY inhibited calcium currents mainly by the activation of $\mathrm{Y} 1$ receptors but also via $\mathrm{Y} 2$ receptors in some neurons (McQuiston et al., 1996). In both nodose neurons and dentate granule neurons, only $30 \%$ of neurons responded to both $\mathrm{Y} 1$ and $\mathrm{Y} 2$ receptor agonists.

In contrast, in the present study almost all of the NP4-sensitive SCN neurons responded to both agonists. The whole-cell barium currents were inhibited in most neurons tested for Y1 and Y2 agonists, although different individual neurons showed different sensitivities to each agonist. This suggests a substantial expression of both Y1- and Y2-like receptors in SCN neurons, at least in the neuron soma. In addition to the inhibition of whole-cell barium currents, the evoked presynaptic GABA release assessed in single autaptic neurons in microcultures also was inhibited by both $\mathrm{Y} 1$ and Y2 agonists in the majority of SCN neurons $(>70 \%)$, indicating a coexistence of Y1- and Y2-like receptors at presynaptic nerve terminals of the same SCN neuron. Furthermore, both the presynaptic release and whole-cell barium currents were inhibited by $\mathrm{Y} 1$ and Y2 agonists in the same neuron. These experiments demonstrate that NPY Y1- and Y2-like receptors coexist in both presynaptic nerve terminals and the postsynaptic cell body in SCN neurons, as depicted by the diagram in Figure 9. The recent demonstration that Y4 and Y5 receptors are expressed in the SCN (Bard et al., 1995; Gerald et al.; 1996; Weinberg et al., 1996) suggests that they could contribute substantially to the effects detected in the present experiment. NPY Y1 and Y4 receptors show greater activation by the agonist $\left[\mathrm{Leu}^{31}, \mathrm{Pro}^{34}\right]$-NPY and Y2 receptors by NPY13-36, but not $\left[\mathrm{Leu}^{31}\right.$, Pro $\left.{ }^{34}\right]-\mathrm{NPY}$. Y5r (Gerald et al., 1996) and Y5m (Weinberg et al., 1996) have a greater sensitivity to the Y1 agonist but also have a mild (10-15 times smaller) response to the Y2 agonist. Our previous work showing that the NPY agonist PYY3-36 evoked a large postsynaptic depression of glutamate actions in the SCN (van den Pol et al., 1996) is consistent with the expression of the Y5r receptor. However, a single NPY receptor such as Y5r could not account for responses to both $\mathrm{Y} 1$ and $\mathrm{Y} 2$ agonists, because the results in the present study demonstrate that some SCN neurons are more sensitive to the Y2 agonist and less to the Y1 agonist, some are the reverse, 
A

Figure 7. Time course of the action of $\mathrm{Y} 1$ and $\mathrm{Y} 2$ agonists on barium currents. $A$, Typical example showing the rapid inhibition by and the rapid recovery of $I_{\mathrm{Ba}}$ after the application of NPY 13-36 and $\left[\mathrm{Leu}^{31}\right.$, Pro $\left.^{34}\right]-N P Y . I_{\mathrm{Ba}}$ was inhibited within $20-30 \mathrm{sec}$ on application of NPY 13-36 or [Leu $\left.{ }^{31}, \mathrm{Pro}^{34}\right]-\mathrm{NPY}$ and returned to the control level within 2 min after washing out the agonists. In this neuron, $\left[\mathrm{Leu}^{31}, \mathrm{Pro}^{34}\right]-\mathrm{NPY}$ produced greater inhibition than NPY 13-36. $B$, Summarized data showing the reduction of $I_{\mathrm{Ba}}$ by NPY, $\left[\mathrm{Leu}^{31}, \mathrm{Pro}^{34}\right]$-NPY, NPY 13-36, and PYY. The amount of reduction in $I_{\mathrm{Ba}}$ was comparable to the reduction in the evoked IPSC (see Fig. 5).

and some are equally sensitive to $\mathrm{Y} 2$ and $\mathrm{Y} 1$ agonists. These data indicate that the relative expression of multiple NPY receptors differs between SCN neurons. As agonists and antagonists that are more selective for the different NPY receptors become available, their use in the SCN should clarify further the roles of the different NPY receptors found here.

\section{Inhibition of calcium currents}

NPY has been demonstrated to inhibit whole-cell calcium (or barium) currents or calcium influx in a number of neurons, mainly peripheral neurons such as rat dorsal root ganglion cells (Walker et al., 1988; Ewald et al., 1989; Bleakman et al., 1991), rat myenteric plexus neurons (Hirning et al., 1990), rat nodose ganglion neurons (Wiley et al., 1993), rat superior cervical ganglion neurons (Foucart et al., 1993; Toth et al., 1993), and central neurons such as rat dentate granule cells (DGC; McQuiston et al., 1996). NPY inhibition seems to be mediated by different NPY receptors in different types of neurons. For example, in DGCs, NPY inhibited calcium currents mainly through Y1-like receptors, and in less than one-third of the cells Y2-like receptors were also involved (McQuiston et al., 1996). In dorsal root ganglion neu-
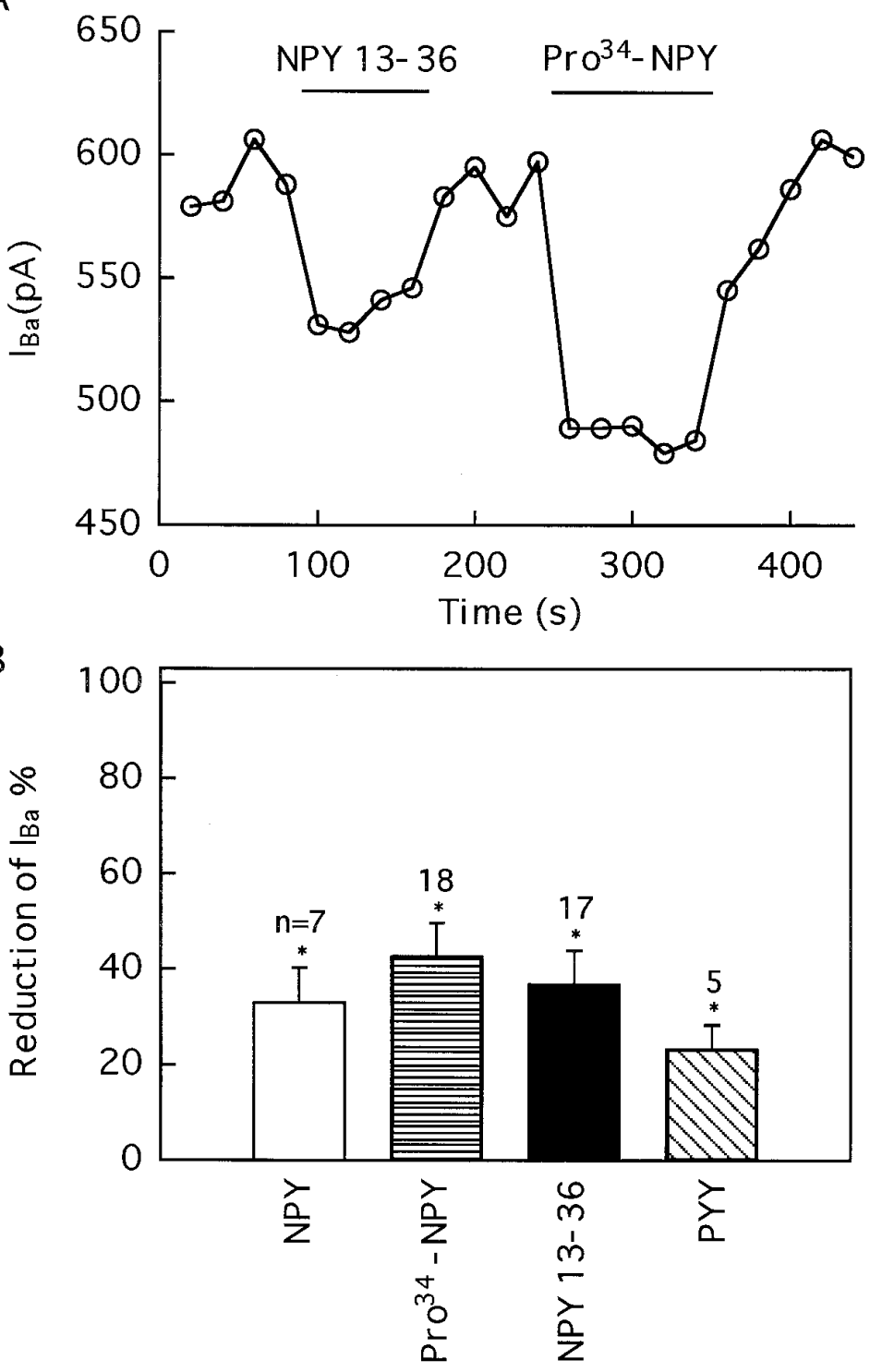

rons, NPY inhibited barium currents via a Y2-like receptor (Bleakman et al., 1991). In nodose neurons, both Y1- and Y2-like receptors were involved in modulating calcium currents but with opposite actions, i.e., Y2 receptor agonist decreased calcium currents, whereas Y1 receptor agonist increased calcium currents (Wiley et al., 1993). In contrast to previous studies, we demonstrate in the present paper that both Y1- and Y2-like receptors coexist in the same SCN neuron and both inhibit barium currents. Furthermore, SCN neurons seem to be more sensitive to NPY than DGCs are. NPY inhibited only $20-30 \%$ of the calcium current (and less with barium currents) at a high NPY concentration of $1 \mu \mathrm{M}$ in DGCs (McQuiston et al., 1996), whereas in the present study NPY inhibited $40-50 \%$ of barium currents at a low concentration of $80 \mathrm{nM}$ in SCN neurons. The site of NPY action is also different between neurons in the hippocampus and in the hypothalamus. In hippocampal pyramidal neurons, NPY had no effect on barium currents but had an inhibitory effect on presynaptic glutamate release (Bleakman et al., 1992). In DGCs, NPY had an inhibitory effect on calcium currents but no effect on presynaptic release (Klapstein and Colmers, 1993; McQuiston et 
A
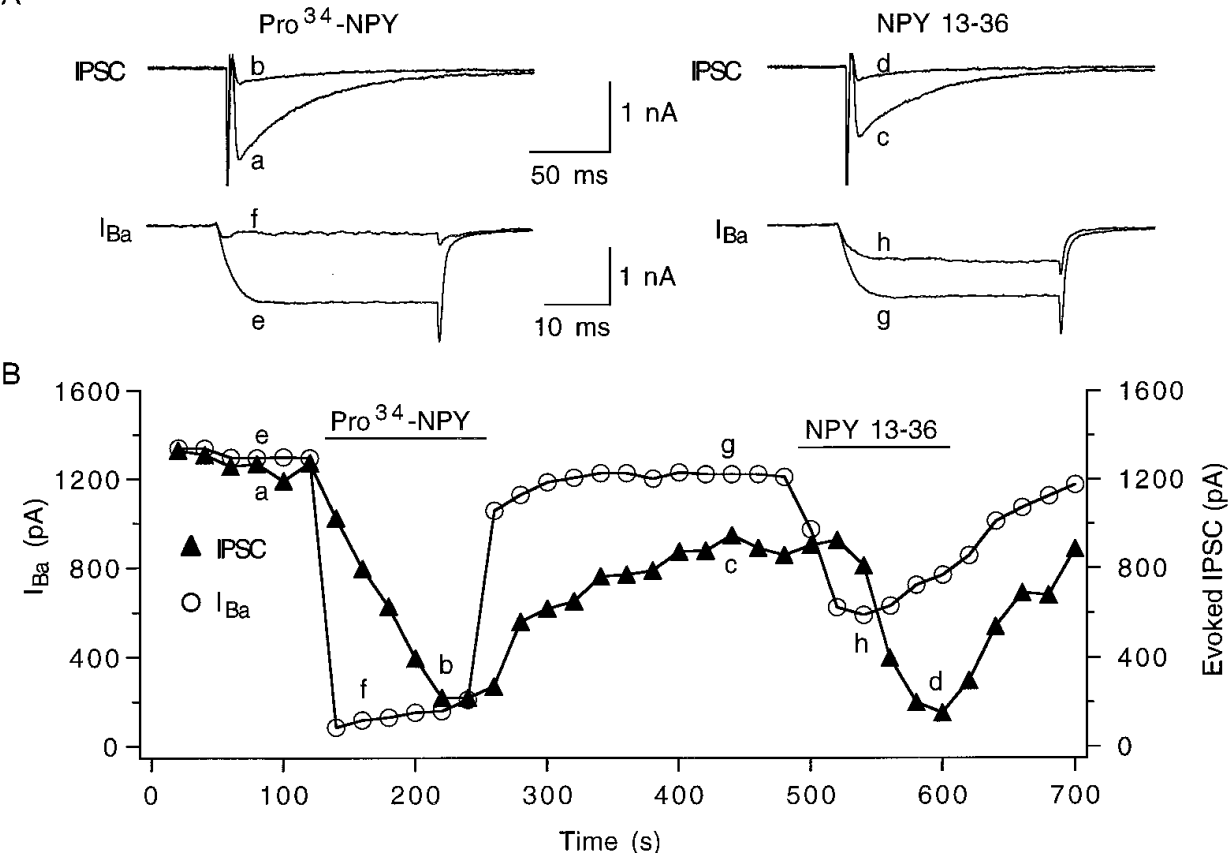

Figure 8. Inhibition of both barium currents and the evoked autaptic GABA release in the same SCN neuron. $A$, Recording traces showing the inhibition of the evoked IPSCs and the $I_{\mathrm{Ba}}$ by $\left[\mathrm{Leu}^{31}, \mathrm{Pro}^{34}\right]-\mathrm{NPY}$ and NPY 1336. Each trace corresponds to a point in B. B, Comparison between the inhibition of the evoked IPSC and the $I_{\mathrm{Ba}}$ by $\left[\mathrm{Leu}^{31}, \mathrm{Pro}^{34}\right.$ ]NPY and NPY 13-36 in the same neuron. Note that the relative amount of the inhibition of the evoked IPSC is proportional to the amount of the inhibition of the $I_{\mathrm{Ba}}$. The time course of the inhibition and the recovery of the evoked IPSC is slower than and follows the $I_{\mathrm{Ba}}$.

al., 1996). In contrast, the present study demonstrates that NPY inhibited both the presynaptic GABA release and the whole-cell barium currents in SCN neurons.

With digital calcium imaging, we showed an inhibitory effect of NPY on GABA-mediated calcium rises in developing hypothalamic neurons (Obrietan and van den Pol, 1996). This was based on a mechanism involving a depolarized $\mathrm{Cl}^{-}$reversal potential (Chen et al., 1996) in which NPY inhibited GABA-mediated depolarizations (Obrietan and van den Pol, 1996). In the present study, we show that NPY can directly modulate voltage-gated calcium channels, independent of GABA actions. In contrast to the presynaptic release, the whole-cell barium currents responded rapidly to NPY and its analogs and also recovered quickly after peptide washout. The inhibition of presynaptic release by NPY was gradual, taking a longer time to reach its minimum amplitude than the inhibition of whole-cell barium currents and usually taking longer to recover. This long-latency recovery of GABA release may serve as a partial mechanistic explanation for the NPY-mediated extended depression of GABA-raised calcium levels in developing SCN neurons (Obrietan and van den Pol, 1996).

The primary excitatory input to the $\mathrm{SCN}$ is glutamatergic, both from retina and nonretinal sources (Kim and Dudek, 1991), and glutamate has been shown to raise the cytosolic calcium of SCN neurons (van den Pol et al., 1992). A large proportion of glutamate-evoked calcium rises is attributable to the opening of voltage-gated calcium channels. The direct NPY inhibition of calcium currents demonstrated in the present paper would serve to reduce glutamate-mediated calcium rises in SCN perikarya (van den Pol et al., 1996), potentially serving to reduce the effectiveness of retinal glutamate in activating gene transcription in a circadian time-dependent manner (Rea, 1989; Kornhauser et al., 1990; Rusak et al., 1990).

\section{Inhibition of GABA release and functional role of NPY in SCN}

The NPY concentration in the rat SCN displays diurnal fluctuations (Calza et al., 1990). This diurnal change in NPY concentration may be important in modulating the circadian rhythm. NPY administration into the SCN phase shifts the circadian rhythm (Albers and Ferris, 1984; Medanic and Gillette, 1993; Shibata and Moore, 1993; Huhman and Albers, 1994), and the direction of the phase shift is dependent on circadian time. The NPY-mediated phase shift can be antagonized by bicuculline (Huhman et al., 1995), suggesting that the action of NPY on circadian rhythms may be mediated by modulation of GABA transmission. This is consistent with the present paper that shows a dramatic inhibition of GABA release by NPY in SCN neurons. Morphological evidence provides further support for this interaction in that GABA terminals and NPY terminals are in direct apposition or converge on the same postsynaptic targets in the rat SCN; NPY colocalizes with GABA, probably in axons from the intergeniculate leaflet of the thalamus (Francois-Bellan et al., 1990).

The density of NPY fibers in the SCN is particularly high; in addition, NPY axons are found throughout the medial hypothalamus (Chronwall et al., 1985), including those regions of the hypothalamus that receive $\mathrm{SCN}$ innervation. Our finding that NPY inhibits transmitter release from presynaptic SCN axons suggests that NPY may be able to modulate the actions of SCN GABAergic axons not only within the nucleus but also at the terminals outside the nucleus by the same presynaptic mechanism described in the present paper.

Most SCN neurons are GABAergic (van den Pol and Tsujimoto, 1985; Okamura et al., 1989; Decavel and van den Pol, 1990; Moore and Speh, 1993; present study), and many SCN neurons have local axon collaterals that terminate on other SCN cells (van den Pol, 1980). That NPY reduces calcium currents could explain previous observations with extracellular recording that NPY is inhibitory (Albers et al., 1990). That excitatory actions of NPY may exist (Mason et al., 1987) could be explained by a reduction in the presynaptic release of GABA, resulting in disinhibition. We have also found that NPY reduces glutamate release from excitatory axons in the SCN (van den Pol et al., 1996). This observation, together with those reported in the present paper, could account for complex response to NPY, including biphasic responses of excitation and inhibition (Liou and Albers, 1991) 
Figure 9. Schematic diagram showing the coexistence of NPY Y1- and Y2-like receptors in both the presynaptic nerve terminals and the postsynaptic cell body.

depending on the time course, mode of application, and circadian state of the SCN. Coupled with the demonstration that single cells express more than one NPY receptor, these data underline the significant level of complexity of NPY actions in the SCN.

\section{REFERENCES}

Adrian TE, Allen JM, Bloom SR, Ghatei MA, Rossor MN, Roberts GW, Crow TJ, Tatemoto K, Polak JM (1983) Neuropeptide Y distribution in human brain. Nature 306:584-586.

Albers HE, Ferris CF (1984) Neuropeptide Y: role in light-dark cycle entrainment of hamster circadian rhythms. Neurosci Lett 50:163-168.

Albers HE, Ottenweller JE, Liou SY, Lumpkin MD, Anderson ER (1990) Neuropeptide $\mathrm{Y}$ in the hypothalamus: effect on corticosterone and single-unit activity. Am J Physiol 258:R376-R382.

Allen YS, Adrian TE, Allen JM, Tatemoto K, Crow TJ, Bloom SR, Polak JM (1983) Neuropeptide Y distribution in the rat brain. Science 221:877-879.

Bard JA, Walker MW, Branchek TA, Weinshank RL (1995) Cloning and functional expression of a human Y4 subtype receptor for pancreatic polypeptide, neuropeptide Y, and peptide YY. J Biol Chem 270:26762-26765.

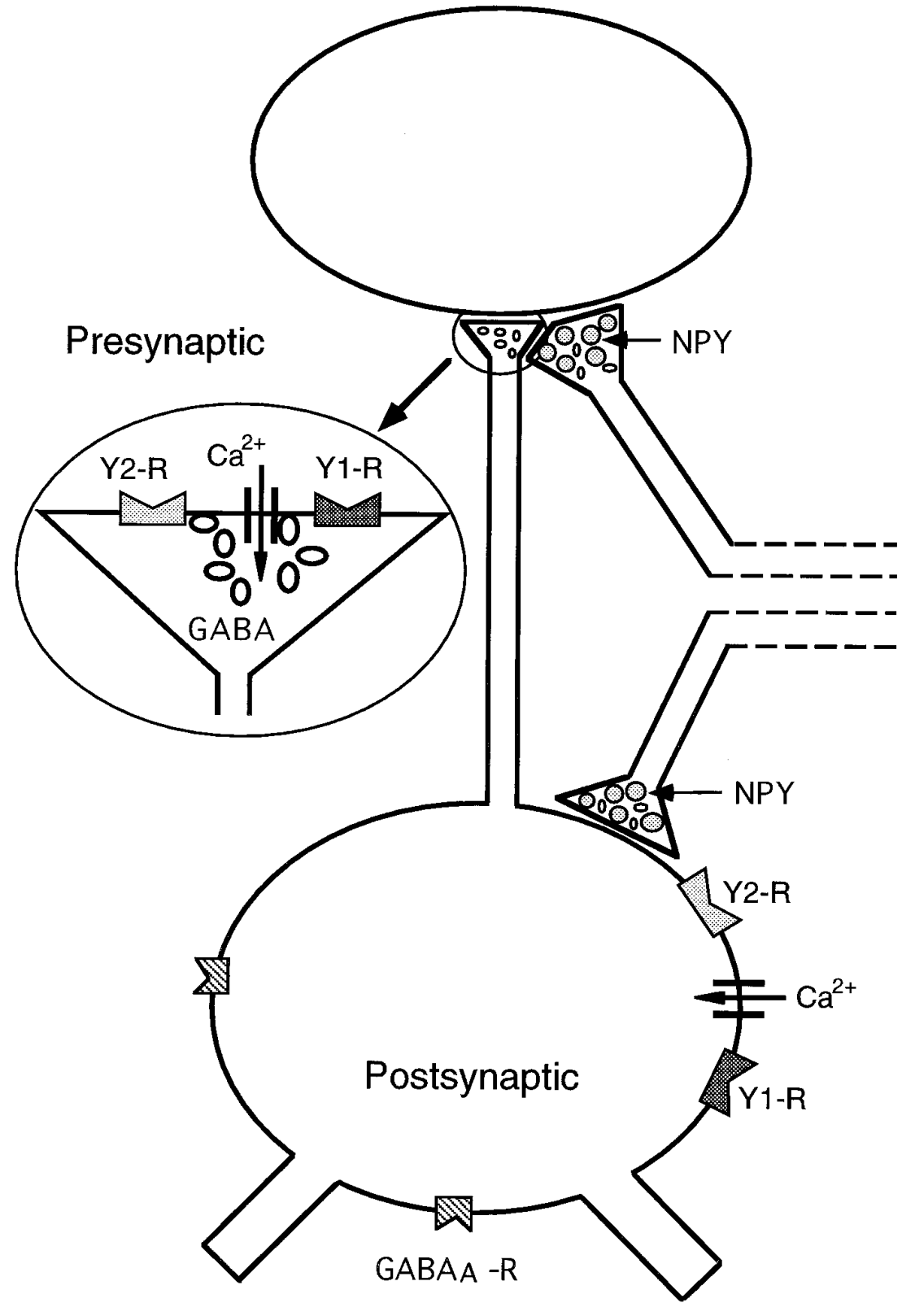

Bekkers JM, Stevens CF (1991) Excitatory and inhibitory autaptic currents in isolated hippocampal neurons maintained in cell culture. Proc Natl Acad Sci USA 88:7834-7838.

Bleakman D, Colmers WF, Fournier A, Miller RJ (1991) Neuropeptide $\mathrm{Y}$ inhibits $\mathrm{Ca}^{2+}$ influx into cultured dorsal root ganglion neurones of the rat via a Y2 receptor. Br J Pharmacol 103:1781-1789.

Bleakman D, Harrison NL, Colmers WF, Miller RJ (1992) Investigations into neuropeptide Y-mediated presynaptic inhibition in cultured hippocampal neurones of the rat. Br J Pharmacol 107:334-340.

Boss NPA, Mirmiran M (1990) Circadian rhythms in spontaneous neuronal discharges of the cultured suprachiasmatic nucleus. Brain Res 511:158-162.

Botchkina GI, Morin LP (1995) Organization of permanent and transient neuropeptide Y-immunoreactive neuron groups and fiber systems in the developing hamster diencephalon. J Comp Neurol 357:573-602.

Calza L, Giardino L, Zanni M, Velardo A, Parchi P, Marrama P (1990) Daily changes of neuropeptide Y-like immunoreactivity in the suprachiasmatic nucleus of the rat. Regul Pept 27:127-137.

Card JP, Moore RY (1989) Organization of lateral geniculatehypothalamic connections in the rat. J Comp Neurol 284:135-147. 
Chen G, Trombley PQ, van den Pol AN (1995) GABA receptors precede glutamate receptors in hypothalamic development: differential regulation by astrocytes. J Neurophysiol 74:1473-1484.

Chen G, Trombley PQ, van den Pol AN (1996) Excitatory actions of GABA in rat developing hypothalamic neurones. J Physiol (Lond) 494:451-464.

Chronwall BM, Chase TN, O'Donohue TL (1984) Coexistence of neuropeptide $\mathrm{Y}$ and somatostatin in rat and human cortical and rat hypothalamic neurons. Neurosci Lett 52:213-217.

Chronwall BM, DiMaggio DA, Massari VJ, Pickel VM, Ruggiero DA, O'Donohue TL (1985) The anatomy of neuropeptide-Y-containing neurons in rat brain. Neuroscience 15:1159-1181.

Colmers WF, Bleakman D (1994) Effects of neuropeptide Y on the electrical properties of neurons. Trends Neurosci 17:373-379.

Colmers WF, Lukowiak K, Pittman QJ (1987) Presynaptic action of neuropeptide $\mathrm{Y}$ in area CA1 of the rat hippocampal slice. J Physiol (Lond) 383:285-299.

Colmers WF, Lukowiak K, Pittman QJ (1988) Neuropeptide Y action in the rat hippocampal slice: site and mechanism of presynaptic inhibition. J Neurosci 8:3827-3837.

Colmers WF, Klapstein GJ, Fournier A, St-Pierre S, Treherne KA (1991) Presynaptic inhibition by neuropeptide $\mathrm{Y}$ in rat hippocampal slice in vitro is mediated by a Y2 receptor. Br J Pharmacol 102:41-44.

Decavel C, van den Pol AN (1990) GABA: a dominant neurotransmitter in the hypothalamus. J Comp Neurol 302:1019-1037.

Ewald DA, Pang IH, Sternweis PC, Miller RJ (1989) Differential G-protein-mediated coupling of neurotransmitter receptors to $\mathrm{Ca}^{2+}$ channels in rat dorsal root ganglion neurons in vitro. Neuron 2:1185-1193.

Foucart S, Bleakman D, Bindokas VP, Miller RJ (1993) Neuropeptide Y and pancreatic polypeptide reduce calcium currents in acutely dissociated neurons from adult rat superior cervical ganglia. J Pharmacol Exp Ther 265:903-909.

Francois-Bellan A, Kachidian P, Dusticier G, Tonon MC, Vaudry H, Bosler O (1990) GABA neurons in the rat suprachiasmatic nucleus: involvement in chemospecific synaptic circuitry and evidence for GADpeptide colocalization. J Neurocytol 19:937-947.

Furshpan EJ, Landis SC, Matsumoto SG, Potter DD (1986) Synaptic functions in rat sympathetic neurons in microcultures. I. Secretion of norepinephrine and acetylcholine. J Neurosci 6:1061-1079.

Garcia de Yebenes E, Li S, Fournier A, St-Pierre S, Pelletier G (1995) Involvement of the $\mathrm{Y} 2$ receptor subtype in the regulation of prolactin gene expression by neuropeptide $\mathrm{Y}$ in the male rat. Neurosci Lett 190:77-80.

Gerald C, Walker MW, Vaysse PJ, He C, Branchek TA, Weinshank RL (1995) Expression cloning and pharmacological characterization of a human hippocampal neuropeptide Y/peptide YY Y2 receptor subtype. J Biol Chem 270:26758-26761.

Gerald C, Walker MW, Criscione L, Gustafson EL, Batzl-Hartmann C, Smith KE, Vaysse PJ, Durkin MM, Laz TM, Linemeyer DL, Schaffhauser AO, Whitebread S, Hofbauer KG, Taber RI, Branchek TA, Weinshank RL (1996) A receptor subtype involved in neuropeptideY-induced food intake. Nature 382:168-171.

Guldner FH, Wolff JR (1978) Self-innervation of dendrites in the rat suprachiasmatic nucleus. Exp Brain Res 32:77-82.

Harrington ME, Nance DM, Rusak B (1985) Neuropeptide Y immunoreactivity in the hamster geniculo-suprachiasmatic tract. Brain Res Bull 15:465-472.

Hendry SH, Jones EG, DeFelipe J, Schmechel D, Brandon C, Emson PC (1984) Neuropeptide-containing neurons of the cerebral cortex are also GABAergic. Proc Natl Acad Sci USA 81:6526-6530.

Herzog H, Baumgartner M, Vivero C, Selbie LA, Auer B, Shine J (1993) Genomic organization, localization, and allelic differences in the gene for the human neuropeptide $\mathrm{Y}$ Y1 receptor. J Biol Chem 268:6703-6707.

Hirning LD, Fox AP, Miller RJ (1990) Inhibition of calcium currents in cultured myenteric neurons by neuropeptide Y: evidence for direct receptor/channel coupling. Brain Res 532:120-130.

Huhman KL, Albers HE (1994) Neuropeptide Y microinjected into the suprachiasmatic region phase shifts circadian rhythms in constant darkness. Peptides 15:1475-1478.

Huhman KL, Babagbemi TO, Albers HE (1995) Bicuculline blocks neuropeptide Y-induced phase advances when microinjected in the suprachiasmatic nucleus of Syrian hamsters. Brain Res 675:333-336.
Inouye ST, Kawamura H (1979) Persistence of circadian rhythmicity in a mammalian hypothalamic "island" containing the suprachiasmatic nucleus. Proc Natl Acad Sci USA 76:5962-5966.

Johnson MD (1994) Synaptic glutamate release by postnatal rat serotonergic neurons in microculture. Neuron 12:433-442.

Kalra SP, Fuentes M, Fournier A, Parker SL, Crowley WR (1992) Involvement of the Y-1 receptor subtype in the regulation of luteinizing hormone secretion by neuropeptide $\mathrm{Y}$ in rats. Endocrinology 130:3323-3330.

Kim YI, Dudek FE (1991) Intracellular electrophysiological study of suprachiasmatic nucleus neurons in rodents: excitatory synaptic mechanisms. J Physiol (Lond) 444:269-287.

Klapstein GJ, Colmers WF (1993) On the sites of presynaptic inhibition by neuropeptide $\mathrm{Y}$ in rat hippocampus in vitro. Hippocampus 3:103-111.

Kornhauser JM, Nelson DE, Mayo KE, Takahashi JS (1990) Photic and circadian regulation of c-fos gene expression in the hamster suprachiasmatic nucleus. Neuron 5:127-134.

Larsen PJ, Jukes KE, Chowdrey HS, Lightman SL, Jessop DS (1994) Neuropeptide-Y potentiates the secretion of vasopressin from the neurointermediate lobe of the rat pituitary gland. Endocrinology 134:1635-1639.

Li S, Hong M, Fournier A, St-Pierre S, Pelletier G (1994) Role of neuropeptide $\mathrm{Y}$ in the regulation of gonadotropin-releasing hormone gene expression in the rat preoptic area. Mol Brain Res 26:69-73.

Liou SY, Albers HE (1991) Single unit response of neurons within the hamster suprachiasmatic nucleus to neuropeptide Y. Brain Res Bull $27: 825-828$.

Lubke J, Markram H, Frotscher M, Sakmann B (1996) Frequency and dendritic distribution of autapses established by layer 5 pyramidal neurons in the developing rat neocortex: comparison with synaptic innervation of adjacent neurons of the same class. J Neurosci 16:3209-3218.

Mason R, Harrington ME, Rusak B (1987) Electrophysiological responses of hamster suprachiasmatic neurones to neuropeptide $\mathrm{Y}$ in the hypothalamic slice preparation. Neurosci Lett 80:173-179.

McDonald JK, Lumpkin MD, Samson WK, McCann SM (1985) Neuropeptide $\mathrm{Y}$ affects secretion of luteinizing hormone and growth hormone in ovariectomized rats. Proc Natl Acad Sci USA 82:561-564.

McQuiston AR, Petrozzino JJ, Connor JA, Colmers WF (1996) Neuropeptide $\mathrm{Y} 1$ receptors inhibit $\mathrm{N}$-type calcium currents and reduce transient calcium increases in rat dentate granule cells. J Neurosci 16:1422-1429.

Medanic M, Gillette MU (1993) Suprachiasmatic circadian pacemaker of rat shows two windows of sensitivity to neuropeptide $\mathrm{Y}$ in vitro. Brain Res 620:281-286.

Moore RY, Card JP (1990) Neuropeptide Y in the circadian timing system. Ann NY Acad Sci 611:247-257.

Moore RY, Eichler VB (1972) Loss of a circadian adrenal corticosterone rhythm following suprachiasmatic lesions in the rat. Brain Res 42:201-206.

Moore RY, Speh JC (1993) GABA is the principal neurotransmitter of the circadian system. Neurosci Lett 150:112-116.

Nakamura M, Sakanaka C, Aoki Y, Ogasawara H, Tsuji T, Kodama H, Matsumoto T, Shimizu T, Noma M (1995) Identification of two isoforms of mouse neuropeptide Y-Y1 receptor generated by alternative splicing. Isolation, genomic structure, and functional expression of the receptors. J Biol Chem 270:30102-30110.

Obrietan K, van den Pol AN (1996) Neuropeptide Y depresses GABAmediated calcium transients in developing suprachiasmatic nucleus neurons: a novel form of calcium long-term depression. J Neurosci 16:3521-3533.

Okamura H, Berod A, Julien JF, Geffard M, Kitahama K, Mallet J, Bobillier P (1989) Demonstration of GABAergic cell bodies in the suprachiasmatic nucleus: in situ hybridization of glutamic acid decarboxylase (GAD) mRNA and immunocytochemistry of GAD and GABA. Neurosci Lett 102:131-136.

Pelletier G (1990) Ultrastructural localization of neuropeptide Y in the hypothalamus. Ann NY Acad Sci 611:232-246.

Ralph MR, Foster RG, Davis FC, Menaker M (1990) Transplanted suprachiasmatic nucleus determines circadian period. Science 247:975-978

Rea M (1989) Light increases fos-related protein immunoreactivity in the rat suprachiasmatic nucleus. Brain Res Bull 23:577-580. 
Rose PM, Fernandes P, Lynch JS, Frazier ST, Fisher SM, Kodukula K, Kienzle B, Seethala R (1995) Cloning and functional expression of a cDNA encoding a human type 2 neuropeptide Y receptor. J Biol Chem 270:22661-22664.

Rusak B, Robertson HA, Wisden W, Hunt SP (1990) Light pulses that shift rhythms induce gene expression in the suprachiasmatic nucleus. Science 248:1237-1240.

Scheenen WJ, Yntema HG, Willems PH, Roubos EW, Lieste JR, Jenks BG (1995) Neuropeptide Y inhibits $\mathrm{Ca}^{2+}$ oscillations, cyclic AMP, and secretion in melanotrope cells of Xenopus laevis via a Y1 receptor. Peptides 16:889-895.

Segal MM (1991) Epileptiform activity in microcultures containing one excitatory hippocampal neuron. J Neurophysiol 65:761-770.

Segal MM (1994) Endogenous bursts underlie seizure-like activity in solitary excitatory hippocampal neurons in microcultures. J Neurophysiol 72:1874-1884.

Shibata S, Moore RY (1993) Neuropeptide Y and optic chiasm stimulation affect suprachiasmatic nucleus circadian function in vitro. Brain Res 615:95-100.

Simonneaux V, Ouichou A, Craft C, Pevet P (1994) Presynaptic and postsynaptic effects of neuropeptide $\mathrm{Y}$ in the rat pineal gland. $\mathrm{J} \mathrm{Neu}-$ rochem 62:2464-2471.

Stephan FK, Zucker I (1972) Circadian rhythms in drinking behavior and locomotor activity of rats are eliminated by hypothalamic lesions. Proc Natl Acad Sci USA 69:1583-1586.

Tatemoto K, Carlquist M, Mutt V (1982) Neuropeptide Y-a novel brain peptide with structural similarities to peptide YY and pancreatic polypeptide. Nature 296:659-660.

Tong G, Malenka RC, Nicoll RA (1996) Long-term potentiation in cultures of single hippocampal granule cells-a presynaptic form of plasticity. Neuron 16:1147-1157.

Toth PT, Bindokas VP, Bleakman D, Colmers WF, Miller RJ (1993) Mechanism of presynaptic inhibition by neuropeptide $\mathrm{Y}$ at sympathetic nerve terminals. Nature 364:635-639.

van den Pol AN (1980) The hypothalamic suprachiasmatic nucleus of rat: intrinsic anatomy. J Comp Neurol 191:661-702. van den Pol AN, Dudek FE (1993) Cellular communication in the circadian clock, the suprachiasmatic nucleus. Neuroscience 56:793-811.

van den Pol AN, Tsujimoto KL (1985) Neurotransmitters of the hypothalamic suprachiasmatic nucleus: immunocytochemical analysis of 25 neuronal antigens. Neuroscience 15:1049-1086.

van den Pol AN, Finkbeiner SM, Cornell BA (1992) Calcium excitability and oscillations in suprachiasmatic nucleus neurons and glia in vitro. J Neurosci 12:2648-2664.

van den Pol AN, Obrietan K, Chen G, Belousov A (1996) Neuropeptide Y-mediated long-term depression of excitatory activity in suprachiasmatic nucleus neurons. J Neurosci 16:5883-5895.

Wahlestedt C, Yanaihara N, Hakanson R (1986) Evidence for different pre-and post-junctional receptors for neuropeptide $\mathrm{Y}$ and related peptides. Regul Pept 13:307-318.

Wahlestedt C, Grundemar L, Hakanson R, Heilig M, Shen GH, Zukowska GZ, Reis DJ (1990) Neuropeptide Y receptor subtypes, Y1 and Y2. Ann NY Acad Sci 611:7-26.

Walker MW, Ewald DA, Perney TM, Miller RJ (1988) Neuropeptide Y modulates neurotransmitter release and $\mathrm{Ca}^{2+}$ currents in rat sensory neurons. J Neurosci 8:2438-2446.

Weinberg DH, Sirinathsinghji DJS, Tan CP, Shiao LL, Morin N, Rigby MR, Heavens RH, Rapoport DR, Bayne ML, Cascieri MA, Strader CD, Linemeyer DL, MacNeil DJ (1996) Cloning and expression of a novel neuropeptide Y receptor. J Biol Chem 271:16435-16438.

Welsh DK, Logothetis DE, Meister M, Reppert SM (1995) Individual neurons dissociated from rat suprachiasmatic nucleus express independently phased circadian firing rhythms. Neuron 14:697-706.

Wiley JW, Gross RA, Lu YX, MacDonald RL (1990) Neuropeptide Y reduces calcium current and inhibits acetylcholine release in nodose neurons via a pertussis toxin-sensitive mechanism. J Neurophysiol 63:1499-1507.

Wiley JW, Gross RA, MacDonald RL (1993) Agonists for neuropeptide Y receptor subtypes NPY-1 and NPY-2 have opposite actions on rat nodose neuron calcium currents. J Neurophysiol 70:324-330. 